FEDERAL RESERVE BANK OF SAN FRANCISCO

WORKING PAPER SERIES

\title{
Collateral Damage: Trade Disruption and the Economic Impact of War
}

\author{
Reuven Glick \\ Federal Reserve Bank of San Francisco \\ and \\ Alan M. Taylor \\ University of California, Davis, NBER, and CEPR
}

Working Paper 2005-11

http://www.frbsf.org/publications/economics/papers/2005/wp05-11.pdf

The views in this paper are solely the responsibility of the authors and should not be interpreted as reflecting the views of the Federal Reserve Bank of San Francisco or the Board of Governors of the Federal Reserve System. 


\title{
Collateral Damage: Trade Disruption and the Economic Impact of War ${ }^{*}$
}

\author{
Reuven Glick
}

Alan M. Taylor

August 2005

Conventional wisdom in economic history suggests that conflict between countries can be enormously disruptive of economic activity, especially international trade. Yet nothing is known empirically about these effects in large samples. We study the effects of war on bilateral trade for almost all countries with available data extending back to 1870 . Using the gravity model, we estimate the contemporaneous and lagged effects of wars on the trade of belligerent nations and neutrals, controlling for other determinants of trade. We find large and persistent impacts of wars on trade, and hence on national and global economic welfare. A rough accounting indicates that such costs might be of the same order of magnitude as the "direct" costs of war, such as lost human capital, as illustrated by case studies of World War I and World War II.

\author{
Reuven Glick \\ Federal Reserve Bank of San Francisco \\ Economic Research Department \\ 101 Market Street \\ San Francisco, CA 94105 \\ 415-974-3184 (Phone) \\ 415-974-2168 (Fax) \\ Reuven.Glick@sf.frb.org \\ Alan M. Taylor \\ University of California, Davis, NBER, and CEPR \\ Department of Economics \\ One Shields Drive \\ Davis, CA 95616-8578 \\ 530-752-1572 (Phone) \\ 530-752-9382 (Fax) \\ amtaylor@ucdavis.edu
}

\footnotetext{
* We thank Marc Meredith, Sandy Naylor, and Radek Szulga for their excellent research assistance. We also thank, without implicating, Steven Broadberry, Herb Emery, Niall Ferguson, Claudia Goldin, Mark Harrison, Joachim Voth, participants at the Fifth World Congress of Cliometrics (Venice, July 2004), seminar participants at the Mershon Center of Ohio State University, the NBER 2005 Development of American History (DAE) Program Meeting, and the CEPR-CREI Conference on "War and the Macroeconomy" (Universitat Pompeu Fabra, June 2005), and members of the Economic History Research list (EH.RES) for helpful comments. The views presented in this paper are those of the authors alone and do not necessarily reflect those of the Federal Reserve Bank of San Francisco or the Board of Governors of the Federal Reserve System.
} 
Trade is a language which prevents people cutting each other's throats.

-Bruce Chatwin ${ }^{1}$

War is hell.

-William Tecumseh Sherman ${ }^{2}$

\section{Introduction}

What are the true costs of war and how can they be measured? One might consult the records of statesmen, the popular press, or the pages of scholarly books and journals, but the approaches to this question vary as widely as the precision of the answers. However, it is fair to say that most analyses have at least one thing in common: a focus on the direct costs, traditionally measured in terms of the loss of life and the resources used to wage war-essentially, men and materiel. To this, occasionally, are added costs of lost and damaged property, although the accuracy of these figures are much more doubtful.

In this paper we examine some major indirect costs of war that have never previously been examined, namely the effect of belligerent conflict on the volume of international trade. Using econometric methods we search for and find a very strong impact of war on trade volumes. Moreover this effect has two important aspects: first, it is persistent, meaning that even after conflicts end, trade does not resume its pre-war level for many years, exacerbating the total costs; second, the effect has a multilateral dimension and, unlike direct costs, which largely effect only the belligerents, trade destruction affects neutral parties as well, generating a negative externality. ${ }^{3}$

Our paper is part of the renaissance of research activity on the applied economics of international trade. A growing theoretical and empirical literature provides strong support for the relation of bilateral trade flows to measures of joint economic activity and costs of trade. These so-called gravity model relationships have been utilized as benchmarks from which to assess the trade impact of economic disturbances and policy regimes, such as exchange rate variability

\footnotetext{
${ }^{1}$ In conversation with James Ivory in Niger, 1973.

${ }^{2}$ In a speech to civil war veterans in Columbus, Ohio, 1880.

${ }^{3}$ In related literature, Hess (2003) estimated the impact of war on consumption losses directly using 1960-1992 data. In work independent of ours, Blomberg and Hess (2004) have studied the impact on trade of various forms of violence, including war and terrorism. Their data covers only the 1968-99 period; our data covers a much longer period including the two great wars.
} 
(Thursby and Thursby 1987), preferential trade arrangements (Frankel, Stein, and Wei 1996), and currency unions (Rose 2000).

The relation of aggregate trade to political disturbances and regimes has received much less attention among economists. This area of analysis has generally been considered to lie more in the domain of political scientists. However, in the political science literature the predominant and most numerous studies have looked at a putative reverse causation-the effect of trade (along with other political variables) on the likelihood of conflict among countries. Few papers have addressed the question of the quantitative impact of conflict itself on trade.

On theoretical grounds, wars and other forms of militarized conflict should reduce trade among adversaries. Military conflict between countries is often accompanied by the imposition of partial or total trade embargoes on the exchange of goods. Conflict may also reduce trade flows by raising the costs to private agents of engaging in international business. The empirical evidence from the few available studies is mixed, however. Pollins (1989a, 1989b), van Bergeijk (1994), and Mansfield and Bronson (1997) estimate gravity models and find that conflict lowers trade. ${ }^{4}$ In contrast, Morrow et al. (1998, 1999), Mansfield and Pevehouse (2000), and Penubarti and Ward (2000) also utilize gravity models, but find that the effect of conflict, though negative, is not statistically significant. ${ }^{5}$ Time series event studies for selected country pairs have also yielded ambiguous results (e.g., Barbieri and Levy 1999; Anderton and Carter 2001).

In addition to failing to provide any uniform conclusion, these studies suffer from several design defects. First, the samples typically are restricted to "politically relevant" cases, defined as country pairs involving one or more major powers and/or geographically contiguous states. The rationale is to exclude country pairs that are especially unlikely or unable to engage in conflict. While this sample restriction limits data collection needs and raises the frequency of conflicts in the data set, it introduces the possibility of bias in the selected sample.

Secondly, these studies do not take account of the possibility that war may have lagged as well as contemporaneous effects on trade. ${ }^{6}$ If war resolves outstanding disputes and creates conditions for profitable exchange soon after war's end, trade may resume rapidly. However, depending on the destructive nature of war on production capacity and trading capabilities, it

\footnotetext{
${ }^{4}$ Mansfield (1994) finds an effect of war on trade at the global level: world trade falls the greater the frequency of conflict among major powers.

${ }^{5}$ Comparisons across these studies are hampered by methodological differences as well.

${ }^{6}$ Pollins (1989b) is an exception, but only considers a lag of one year.
} 
may take a while to exploit these opportunities. In addition, if the threat of additional military actions in the future remains, trade will recover slowly after the cessation of war. ${ }^{7}$ Thus, even with the end of war, trade may remain depressed for several years thereafter, due to the costs and inconveniences of postwar reconstruction, diplomatic tensions, explicit price or quantity controls on trade, and other forms of disruption. How quickly and how much trade rebounds is an empirical question that should be of interest to understanding the overall effects of conflict on trade.

Thirdly, most studies use pooled, rather than panel, estimators that may not adequately control for omitted country- or pair-specific attributes, nor effectively distinguish between the effects of conflict on trade across country pairs and the effects over time. To combat this problem we turn to a gravity model with panel data using country-pair fixed effects (CPFE) estimation, so that identification of the impact of war is conducted entirely in the time dimension with full control for any time-invariant pair characteristics. ${ }^{8}$

In our paper we analyze the effect of war and other forms of militarized conflict on international trade. A data set covering a large number of countries over the period 1870-1997 enables estimation of this effect across time as well as across countries. By comparing the bilateral trade among belligerent and neutral countries during and after conflicts (holding fixed other factors), we estimate the contemporaneous and lagged effects of war on trade. We then use these coefficient estimates in various counterfactual experiments to calculate the aggregate effects of conflict on world trade, particularly the costs of the two world wars of the 20th century.

Finally, we also make an estimate of the welfare costs of these trade shocks using an income metric. These costs are then compared to traditional direct costs, such as the valuations of the loss of life. We find that the costs of war due to trade disruption, although typically ignored, appear to have been relatively large.

\footnotetext{
${ }^{7}$ An exception is when victorious countries choose to help rebuild the economies of the losers after war, as in the case of the Allied treatment of Germany and Japan after World War II.

${ }^{8}$ The reliance on pooled estimation techniques also complicates analyses of the reverse direction of causality between conflict and trade. Consequently, the conflict literature appears better able to answer the question of which countries engage in conflict rather than when countries engage in conflict, a point to which we shall return.
} 


\section{Methodology and Data}

\section{Gravity Model Methodology}

The effects of war on international trade are estimated using a conventional gravity model of international trade, which is now the benchmark empirical model for this kind of exercise. ${ }^{9}$ In this model we specify the average level of trade between any two countries as a function of the log distance between them, the log of the product of their GDPs, and other control variables, as well as the current and lagged effects of countries at war:

$$
\begin{aligned}
& \ln \left(\text { Trade }_{\mathrm{ijt}}\right)=\beta_{0}+\sum_{\mathrm{k}} \gamma_{\mathrm{k}} \text { War }_{\mathrm{ij}, \mathrm{t}-\mathrm{k}} \sum_{\mathrm{k}} \lambda_{\mathrm{k}} \text { Neutral }_{\mathrm{ij}, \mathrm{t}-\mathrm{k}}+\beta_{1} \ln \left(\mathrm{Y}_{\mathrm{i}} \mathrm{Y}_{\mathrm{j}}\right)_{\mathrm{t}}+\beta_{2} \ln \left(\mathrm{Y}_{\mathrm{i}} \mathrm{Y}_{\mathrm{j}} / \text { Pop }_{\mathrm{i}} \mathrm{Pop}_{\mathrm{j}}\right)_{\mathrm{t}} \\
& +\beta_{3} \operatorname{lnDist}_{\mathrm{ij}}+\beta_{4} \operatorname{Lang}_{\mathrm{ij}}+\beta_{5} \text { Border }_{\mathrm{ij}}+\beta_{6} \text { Landl }_{\mathrm{ij}}+\beta_{7} \text { Island }_{\mathrm{ij}}+\beta_{8} \ln \left(\text { Area }_{\mathrm{i}} \text { Area }_{\mathrm{j}}\right) \\
& \quad+\beta_{9} \text { CurCol }_{\mathrm{ijt}}+\beta_{10} \text { Colony }_{\mathrm{ij}}+\beta_{11} \text { CurU }_{\mathrm{ijt}}+\varepsilon_{\mathrm{ijt}}
\end{aligned}
$$

where $\mathrm{i}$ and $\mathrm{j}$ denotes countries, $\mathrm{t}$ denotes time, and the variables are defined as:

- Trade $_{\mathrm{ijt}}$, the average value of real bilateral trade between countries $\mathrm{i}$ and $\mathrm{j}$ at time $\mathrm{t}$;

- War is a binary variable which is unity if $i$ and $j$ were engaged in a war against each other (directly or via colonial relationships) in period $\mathrm{t}-\mathrm{k}, \mathrm{k}=0,1, \ldots \mathrm{M}$;

- Neutral is a binary variable which is unity if either $\mathrm{i}$ or $\mathrm{j}$ is neutral while the other is engaged in a war against some third country in period $\mathrm{t}-\mathrm{k}, \mathrm{k}=0,1, \ldots \mathrm{M}$;

- $\mathrm{Y}$ is real GDP;

- Pop is population;

- Dist is the (great circle) distance between the capital cities of $i$ and $j$;

- Lang is a binary variable which is unity if $\mathrm{i}$ and $\mathrm{j}$ have a common language;

- Border is a binary variable which is unity if $i$ and $j$ share a land border;

- Landl is the number of landlocked countries in the country-pair $(0,1$, or 2$)$;

- Island is the number of island nations in the pair $(0,1$, or 2$)$;

- Area is the land mass of the country;

- $\mathrm{CurCol}$ is a binary variable which is unity if $\mathrm{i}$ and $\mathrm{j}$ are colonies at time $\mathrm{t}$ or vice versa;

\footnotetext{
${ }^{9}$ Gravity models have been much discussed in the literature. Frankel (1997) provides a thorough review of the model; Rose (2000) provides references.
} 
- Colony is a binary variable which is unity if i ever colonized $\mathrm{j}$ or vice versa;

- CurU is a binary variable which is unity if $i$ and $j$ are engaged in a currency union at time $t$;

- $\gamma_{\mathrm{k}}, \lambda_{\mathrm{k}}, \beta_{\mathrm{i}}$ are coefficients; and

- $\varepsilon_{\mathrm{ij}}$ represents the myriad other influences on bilateral trade, assumed to be well behaved.

The coefficients of main interest to us are $\gamma_{\mathrm{k}}$ and $\lambda_{\mathrm{k}}$. The former describe the impact of war on $\log$ trade levels for adversary country pairs; the latter describes the same impact on adversaryneutral country pairs. The contemporaneous effect of war among countries at war with each other is captured by $\gamma_{0}$, while the lagged effects of a war ending k periods previously is captured by $\gamma_{\mathrm{k}}, \mathrm{k}=1, \ldots \mathrm{M}$, where $\mathrm{M}$ is the maximum lag length. $\lambda_{0}$ and $\lambda_{\mathrm{k}}$ analogously capture the contemporaneous and lagged effects of war on trade between belligerents and neutral countries. ${ }^{10}$

The model is estimated with a number of techniques below. However, we generally rely on the robust fixed effects "within" estimator, which essentially adds a set of country-pair fixed effects (CPFE) or intercepts to the equation and controls for omitted country characteristics that do not vary across time, including any time-invariant component of multilateral resistance (Anderson and van Wincoop 2004). Regrettably, serious data limitations, including a severely unbalanced dataset over more than a century, preclude the inclusion of a fully-specified, timevarying multilateral resistance term. We also include historical measures of currency arrangements to examine the effects of a common currency post-1945 and the gold standard pre1945 (cf. Glick and Rose 2002; Estevadeordal, Frantz, and Taylor 2003).

\section{Dataset}

The bilateral trade data were assembled from three main sources: (i) the IMF "Direction of Trade", (ii) Barbieri (1996), and (iii) Mitchell (1992, 1993, 1998).

The IMF "Direction of Trade" (DoT) data cover bilateral trade between 217 IMF country-code geographical units between 1948 and 1997 (with many gaps). Bilateral trade on FOB exports and CIF imports is recorded in U.S. dollars; trade is deflated by the U.S. CPI (based to 1985). Since exports and import figures may be available from both countries, there are potentially four measured bilateral trade flows: exports from $i$ to $j$, exports from $j$ to $i$, imports

\footnotetext{
${ }^{10}$ In the case of multi-year wars, the lags of war are dated from the last year of the conflict. We assume that for a war ending at time $t$, if a new war occurs at time $t$ ' $>t$, the values of the war variable lags of the first war are "reset" to zero at the time the subsequent war begins, i.e., $\operatorname{War}_{t-k}=0$ for $k \geq t^{\prime}-t$.
} 
into $i$ from $j$, and imports into $\mathrm{j}$ from $\mathrm{i}$. An average value of bilateral trade between a pair of countries is created by averaging all of the four possible measures potentially available. Observations where all four figures have a zero or missing value are dropped from the sample. ${ }^{11}$ The Barbieri (1996) dataset contains bilateral trade data in current U.S. dollars for some 60 countries during the period $1870-1947 .{ }^{12}$ Her data typically measure bilateral trade between countries $i$ and $i$ by summing imports into $i$ from $j$ and into $j$ from $i$; we divide these figures in half to construct an average value of bilateral trade. The figures are deflated by the U.S. CPI index. We used data from Mitchell $(1992,1993,1998)$ to fill out the sample with missing observations among major trade partners during the period 1870-1947 and to correct obvious errors in Barbieri's data. These data are typically reported in local currency units. We converted them into current U.S. dollar terms using available exchange rate data and then deflated them by the U.S. CPI. Further details are in the Data Appendix.

To this dataset, a number of other standard variables are added to estimate a gravity model; these include real GDP, population, and various country-pair characteristics, such contiguity, distance, etc. Real GDP and per capita GDP data (in constant 1985 dollars) for the 1948-97 period are obtained from three sources. Wherever possible, data from the World Bank's World Development Indicators (from the $2000 \mathrm{CD}-\mathrm{ROM}$ ) are used. When the WDI data are unavailable, missing observations are filled in with comparables from the Penn World Table (PWT) Mark 5.6, Maddison (1995) ${ }^{13}$, and (when all else fails) from the IMF's International Financial Statistics. ${ }^{14}$ For the $1870-1947$ period we draw primarily on data from Maddison (1995; 2001), supplemented by information from Mitchell $(1992,1993,1998)$ and individual country sources. The resulting series are then put into constant 1985 dollars and linked to the 1948-97 series. (See the Data Appendix.)

The CIA's World Factbook is used to provide a number of country-specific variables, including latitude and longitude, land area, landlocked and island status, physically contiguous

\footnotetext{
${ }^{11}$ These data are essentially the same as that used by Glick and Rose (2002).

12 We use version 1.1 of Barbieri's International Trade dataset obtained from the webpage http://pss.la.psu.edu/trd_data.htm. These data actually extend to 1992; we rely on the original source data reported by the DoT for the $1948-1997$ period.

${ }^{13}$ Maddison calculates his historical series on GDP and GDP per capita for constant 1990 territorial areas and borders. Whenever possible we make adjustments to GDP to take account of territorial size changes due to wars, etc. See the Appendix for details.

${ }^{14}$ The IFS-based series are calculated by converting national currency GDP figures into dollars at the current dollar exchange rate and then dividing by the U.S. CPI.
} 
neighbors, language, colonizers, and dates of independence. ${ }^{15}$ These are used to create greatcircle distance and the other controls. Whenever appropriate, we make changes in land area to reflect territorial changes based on historical sources.

For the 1948-97 period we use the currency union variable constructed by Glick and Rose (2002), defined as country pairs for which money is interchangeable at 1:1 par for an extended period of time. ${ }^{16}$ For the pre-1948 period, we set CurU equal to one for counties on the gold standard, allowing for a similar currency effect, following Estevadeordal, Frantz, and Taylor (2003), and using data on gold standard arrangements from Obstfeld and Taylor (2003). ${ }^{17}$

Our measure of war is constructed from the database on militarized interstate disputes (MID) collected by the Correlates of War Project (COW) at the University of Michigan. We use Maoz's dyadic data set DYMID1.1, a revised version of the COW dataset MID2.1 compiled by Jones, Bremer, and Singer (1996). ${ }^{18}$ This data set codes the level of hostility reached in a given country's conflict with an opposing state(s), where 2 = "threat of force", 3 = "display of force", 4 = "use of force" (short of war, but including formal declarations of war not accompanied by fatalities), and 5 = "war." We code our war variable as conflicts with hostility level 5 (which generally involve conflicts with more than 1,000 battle deaths), as well as declarations of war (hostility level 4, and HiAct = 20). ${ }^{19}$ The data set is extended from 1992 through 1997 with information on "Major Episodes of Political Violence, 1946-1999" from the University of Maryland's Center for Systemic Peace (CSP) and The Statesman's Yearbook. ${ }^{20}$ Countries at war with a colonial power are treated as being at war with its current colonies, i.e., if country pair $\mathrm{i}-\mathrm{j}$ are at war, and j-k are in a colonial relationship, then i-k are also assumed to be at war.

\footnotetext{
${ }^{15}$ The website is: http://www.odci.gov/cia/publications/factbook.

${ }^{16}$ Hard fixes at non 1:1 rates (such as those of Hong Kong, Estonia, or Denmark) do not qualify as currency unions under this definition.

${ }^{17}$ On the gold standard and trade see also Flandreau and Maurel (2001) and López-Córdova and Meissner (2003).

${ }^{18}$ The website for the Maoz dataset is http://spirit.tau.ac.il/zeevmaoz.

19 The COW data set arbitrarily limits the length of conflict at six months for countries that declared war but did not actually fight against their declared adversaries (e.g., various Latin American countries declared war against the Axis powers, but did not actually send troops to the war theaters). We assume that countries declaring war during World Wars I and II were at war until the state of war was formally revoked or the declared adversary was deemed defeated. "HiAct" is short for "highest action in dispute." This is an index representing the type of conflict and supplements the 1-5 hostility level index; the higher the number, generally, the more intense the conflict. See the MID codebook at http://cow2.la.psu.edu.

${ }^{20}$ The CSP webpage is http://members.aol.com/CSPmgm/cspframe.htm. We also cross-checked our conflict coding with the 3.0 version of the COW dataset, which was released after our dataset was assembled; no changes were deemed necessary. Extending the sample beyond 1997 would have little effect since there have been no major wars until the U.S. actions in Afghanistan in 2001 and Irqa in 2003.
} 
Table 1 presents some summary statistics on the number of observations and the frequency of war for the full sample 1870-1997, as well as for the two subsamples 1870-1938 and 1939-1997. These statistics are conditional on the availability of data on bilateral trade and GDP, the main constraints for the inclusion of observations in our gravity model estimation.

Our full sample contains 251,905 bilateral trade observations involving 172 countries and 11,535 different country pairs. Not surprisingly, the bulk of these observations are in the later sample, as the number of countries proliferated and more data on trade and GDP has become available. War is a relatively infrequent occurrence in our sample. Conditional on the availability of contemporaneous trade and GDP data, only 75 different country-pairs with 206 country-year observations (since a conflict involving a particular pair may last more than one year) involve war adversaries. However, many countries at war lack contemporaneous trade and/or GDP data while engaged in conflict. When we extend the count by including observations of (up to 10 years of) lagged war, while still conditioning on trade and GDP data availability for these years, the number of country-pairs at war in the sample rises to 338. Correspondingly, the number of pair-year observations rises to 2143 , amounting to $0.85 \%(=2143 / 251905)$ of the total sample. While the frequency of war observations in the pre-World War II period is somewhat higher $(2.97 \%=410 / 13804)$, wars are still rare events. It is worth noting that even though major conflicts are infrequent, most countries in the sample have been involved in war at one time or the other. Of the 172 countries, over 60\% (104) have been engaged in war sometime during our sample period. We now proceed to show that wars, while relatively infrequent, have had large effects on trade.

\section{Gravity-Based Estimates of the Effect of War on Trade}

\section{Benchmark Estimates}

We begin by estimating our gravity equation using a country-pair fixed effect (CPFE) panel estimator (with a full set of year-specific intercepts added). Standard errors are clustered at the country-pair level to address potential problems of heteroskedasticity and autocorrelation in the error terms. $^{21}$ The War dummy is allowed to enter contemporaneously and with up to ten yearly

\footnotetext{
${ }^{21}$ Clustering at the country pair level allows the variance to differ across pairs and permits an unstructured covariance within the clusters to control for correlation across time. Bertrand, Duflo, and Mullainathan (2004) suggest clustering as the best way to handle autocorrelation in panel differences-in-differences estimation, which can
} 
lags (denoted Warl to War10). The Neutral variable is initially excluded from the regressor list. Results are presented in Table 2 (the fixed effects for pairs and years are not reported). Since some traditional gravity variables like distance, shared land borders, or island status, are both time-invariant and pair specific, they are collinear with the pair fixed effects and drop out. However, they will reappear in alternative specifications that we employ for robustness checks later on.

The model proves successful on a number of different dimensions. The model fits the data well, explaining almost one-half of the variation in bilateral trade flows. The added control variables are economically and statistically significant with sensible interpretations. For instance, economically larger and richer countries trade more. A common currency encourages trade, as does a common, ongoing colonial relationship.

The key variables of interest in this paper are the $\gamma_{\mathrm{k}}$ estimates of the "trade destruction" impact of war. The fixed effect "within" estimator measures $\gamma_{k}$ by comparing trade for a pair of countries at war to trade for the same pair of countries when not at war. It exploits variation over time and answers the time series question: "What is the effect on trade (now and in the future) of a country being at war?" The coefficients indicate that the contemporaneous and lagged effects on trade are all negative, with significant effects persisting for 8 years or more. The contemporaneous effect is -1.78 , implying that trade between two adversaries at war falls by over 80 percent (since $1-\mathrm{e}^{-1.78} \approx .83$ ), relative to its peacetime prewar counterfactual level, a very large reduction. Once the war ends, the extent of trade destruction declines monotonically overtime, and trade returns to its "normal" prewar level about a decade later. Trade is still $42 \%$ below the prewar level five years after the cessation of war and $21 \%$ below even after eight years. $^{22}$ These effects are economically large and generally statistically significant at conventional levels. Dropping the year dummies implies slightly larger effects.

\section{Robustness Checks: Different Estimators, Subperiods, and Regressors}

To provide some sensitivity analysis, the basic methodology is perturbed in a number of different ways. Table 3 reports the robustness of the results to alternative estimators: (i) a random effects

be viewed as a variant of fixed-effect panel estimation; this approach has been followed in other applications of CPFE (see, e.g., Klein and Shambaugh 2005).

${ }^{22}$ Since $1-\mathrm{e}^{-.55} \approx .42$ and $1-\mathrm{e}^{-.24} \approx .21$. For lags one to five the coefficients average -.99 , implying $1-\mathrm{e}^{-.99} \approx .63$, while for lags six to ten they average -.19 , implying $1-\mathrm{e}^{-.19} \approx .18$. 
panel estimator (which assumes the disturbances are uncorrelated with the random country-pair specific effects); (ii) a maximum-likelihood estimator; (iii) an OLS estimator applied to the pooled data, with standard errors robust to clustering for common country-pair observations; and (iv) an OLS estimator employed with individual country dummies rather than pair dummies. The last specification is now commonplace in gravity modeling, since, rather than using up degrees of freedom with a full set of time-country interactions, it provides a consistent estimate of "average treatment effects" for other controls (like war) even when the multilateral resistance is time varying (Feenstra 2002). To conform with the specification of the so-called "theoretical" gravity model, this case also constrains the coefficient on the product of GDPs to unity, thus effectively redefining the dependent variable as the $(\log )$ ratio of bilateral trade to GDP. Year dummies are included in all cases. The results of Table 3 show that the $\gamma$ estimates are reasonably insensitive to all of these different estimators. The war effects remain: they are consistently large economically, and statistically significant throughout.

We next perturb the model by dividing the sample into two subperiods (1870-1938 and 1939-1997) and also by isolating the effects of World War I and World War II from other wars. The results are reported in Table 4. The results for the full sample from the first column of Table 1 are presented in the first column of Table 4 as a benchmark for comparison. A country-pair fixed effect (CPFE) estimator is employed in all cases. We observe that the effects of wars are negative in both sample subperiods, with the contemporaneous effects slightly higher (in absolute value), but the lagged effects decaying more rapidly, in the 1870-1938 period than in the 1939-1997 period. In the first period, a significantly negative effect of war on trade lasts only four years, compared to nine years in the latter period. Focusing on the effects of the two World Wars alone indicates that their effects on trade are larger than that of other wars. The estimated contemporaneous coefficient for World War I of -3.02 implies a decline in trade of $95 \%$; the corresponding coefficient for World War II of -2.74 implies a similarly high decline in trade of $94 \%$. In the major wars, it would appear that trade between adversaries was almost totally destroyed.

Table 5 augments the results in Table 4 by including the effects of war on trade between belligerents and neutral countries, where these pairs are identified by the dummy variable Neutral. As with the War variable, persistent effects are admitted via ten lags, Neutrall to Neutral10. Inclusion of the neutrals does not change the economic and statistical significance of 
the war effects. The coefficient magnitudes on trade among adversaries are essentially unaffected relative to prior estimates, but the negative coefficients on the Neutral variables imply that war also depresses trade between belligerents and neutrals. For the full sample, in Table 5, Column 1, trade with neutrals declines by 12 percent $\left(\approx 1-\mathrm{e}^{-0.13}\right)$ in wartime, and the negative effect of war on trade for these pairs persists with a lag for up to seven years with statistical significance. Inspection of the subperiod results reported in the other columns of Table 5 reveals the same basic pattern, though the contemporaneous effect on neutrals for the 1870-1938 period appears to be somewhat smaller. Isolating the effects of World War I and II alone shows much larger effects on trade between neutrals and belligerents. The estimated contemporaneous coefficient for World War I of -0.54 implies a decline in trade of $42 \%$; the corresponding coefficient for World War II of -1.06 implies a similarly high decline in trade of $65 \%$.

These results lead to the first major conclusion of this paper: historically, wars have been very damaging for world trade. As might seem obvious, war depresses trade between belligerents, but we can provide an estimate of this effect and it is very large: a decline in trade of about 80 to 90 percent. Moreover, war creates negative externalities on trade even for neutral countries: their trade with belligerents is also adversely affected, being subject to a decline of about 5 to 12 percent. Lastly, both of these effects persist for almost ten years, as shown in Figure 1 (based on the coefficients in column 1 of Table 5).

In practice, what has this meant for the impact of wars on the world economy? Small wars involve few belligerents but many neutrals. These are likely to have a large global effect only if the belligerents are large countries. But the major wars in history have had catastrophic impacts on world trade: the belligerents accounted for a large share of world trade-with themselves and with neutrals. To illustrate the potential magnitude of these effects we look at the two World Wars as case studies using our model in Section 4. Before doing so, we conduct a final robustness check by addressing possible concerns about the endogeneity of war and trade.

\section{Robustness Check: Simultaneity Concerns}

The analysis till now has treated the occurrence of wars and conflict as events that are exogenous to trade. What if trade and war are endogenously related to each other? That is, trade may depend on war, but the occurrence of wars may depend directly on the trade interdependence between members of a country pair. In fact, there is a vast political science literature that addresses the 
question of how the likelihood of conflict among nations depends on various measures of economic interdependence, including the level of bilateral trade or trade openness, in addition to various geographic and political regime variables.

On both theoretical and empirical grounds, the effect of trade on conflict in the political science literature is generally mixed. The "realist" view argues that trade may create conflict by intensifying competition and/or increasing dependence on strategic goods. Opposing "liberal peace" proponents argue that trade interdependence deters conflict and promotes peace by generating economic benefits and raising the costs of conflict. Barbieri $(1996,2002)$ and Beck, Katz, and Tucker (1998) find either a positive or negligible effect of trade on the likelihood of conflict, while Polachek (1990), Oneal and Russett (1997, 1999) and Mansfield and Pevehouse (2000) find evidence that trade reduces conflicts. ${ }^{23}$

Nonetheless, in our case we have reason to believe that simultaneity is not a serious problem for our gravity model results. Before we present the evidence, we offer the following intuition. Most of the evidence of a significant effect of conflict on trade involves cross-pair variations in the data, not with-in pair time effects. The former is of no concern to us since we use country-pair fixed effects throughout our analysis. Whether a given country pair is more or less likely to engage in war is factored out through that fixed effect. Our identification of the effect of war on trade is purely in the time dimension. Since levels of trade between countries are very slowly varying over time (and to a large degree explained by slowly-changing or unchanging covariates such as country size and distance), the use of trade levels to forecast a war is a priori a hopeless cause. Trade measures may tell us something about which pairs are more or less likely to go to war; they tell us nothing about when those countries will actually go to war.

To establish this result, we proceed by estimating a model of the likelihood that country pairs engage in war. The likelihood of war is specified as a function of bilateral trade dependence, as well as of common land borders (Border), joint alliance membership (Alliance),

\footnotetext{
${ }^{23}$ For a survey of the political science literature on the links between trade and conflict, see Barbieri and Schneider (1999), Reuveny (2000), and the papers in Mansfield and Pollins (2003). Many of these results in this literature appear to be sensitive to the exact measures of trade, the sample used, and whether any controls are applied to measure not only the level of bilateral trade levels, but also its symmetry and its importance to the countries in question. Barbieri (2002) argues that the basic liberal position is an illusion, but finds that trade asymmetry matters. Martin, Mayer, and Thoenig (2005) using a 1948-2001 sample period have recently reported that countries trading more bilaterally have a lower probability of conflict, while countries that are more open to trade overall have a higher probability of war because multilateral trade openness decreases dependence on any given country.
} 
major power status of one or more of the pair (MajPower), and the number of years of peace (YrsPeace):

$$
\begin{gathered}
\text { War }_{\mathrm{ijt}}=\alpha_{0}+\alpha_{1} \ln \left(\operatorname{Trade}_{\mathrm{ij}} / \mathrm{Y}_{\mathrm{i}} \mathrm{Y}_{\mathrm{j}}\right)_{\mathrm{t}-2}+\alpha_{2} \text { Border }_{\mathrm{ij}}+\alpha_{3} \text { Alliance }_{\mathrm{ijt}-2} \\
+\alpha_{4} \text { MajPower }_{\mathrm{ij}}+\alpha_{5} \text { YrsPeace }_{\mathrm{ij}, \mathrm{t}-2}+\varepsilon_{\mathrm{ijt}}
\end{gathered}
$$

Countries that trade more bilaterally should - if the liberal argument holds-have a lower likelihood of war because of the opportunity cost associated with the loss of trade gains. The likelihood of conflict should be greater for adjacent countries, since contiguity and closer geographic proximity facilitate confrontations over such matters as land borders. The likelihood of conflict should also be greater for countries participating in alliances. The expected effect of major power status is a priori ambiguous. On the one hand, major-power states are more likely to engage in military conflict since they have wide-ranging interests that potentially bring them into conflict with a large number of states. On the other hand, their military capabilities may work to discourage actual conflict.

We measure bilateral trade dependence as the log of bilateral trade relative to the product of the pair country GDPs. MajPower is a dummy variable $=1$ if any member of the pair includes the United States, the United Kingdom, Germany, France, Japan, or USSR/Russia. The Alliance variable is a binary dummy based on data from the Correlates of War project, which codes three types of alliance pacts in order of decreasing level of commitment: $1=$ defense, $2=$ nonaggression/neutrality, 3 = entente. We code Alliance $=1$ when ever countries are linked by any of these forms of alliance. ${ }^{24}$ Given the binary nature of conflict observations, the probability of conflict among any particular country pair should also depend on how long since the pair has previously been in conflict. To control for this temporal relation we include the variable YrsPeace that measures the number of years since the previous war between the pair. ${ }^{25}$ Time

\footnotetext{
${ }^{24}$ Our data source is the file "AllianceData_July2000.txt" distributed by the Expected Utility Generation and Data Management Program (EUGENE), v 2.013, available from the website: http//eugenesoftware.org. This file extends the original COW data from 1984 to 1992. We have augmented the dataset to include missing members of the Arab League, Council of Independent States, Gulf Cooperation Council, Organization of African Unity, Organization of American States, and Organization of East Caribbean States. We assume that all alliance relationships in effect in 1992 extend through 1997.

${ }^{25}$ For countries in existence in 1870 the years of peace variable begins counting from 1812 or the most recent occurrence of war prior to 1870 . Former colonies and other states newly independent after 1870 "inherit" the war memory of their parent colonizers.
} 
varying variables are lagged two years to limit simultaneity issues. A full set of year dummies are also used in our specification. ${ }^{26}$

Table 6 presents estimates of the war model using pooled logit and conditional fixed effect panel logit estimators. Standard errors robust to clustering for common country-pair observations are provided throughout. We report results for the full sample 1870-97, and for the subperiods 1870-1938 and 1939-1997.

The pooled logit results reported in the first three columns indicate that the likelihood of conflicts increases when country pairs are contiguous, decreases when an alliance relation exists or a major power is involved, and decreases the longer the period of peace between any pair of countries (the coefficients for YrsPeace are divided by 100 to improve readability of results); these effects are all statistically significant, typically at better than 1 percent, for the full sample and the more recent subperiod. Most importantly, Table 6 indicates that trade dependence significantly decreases the risk of war at better than $1 \%$ for the full sample as well as both subperiods. This suggests that there may indeed be some reverse causality between the extent of bilateral trade relations and the possibility of war.

The results with country-pair fixed effects, however, show exactly what is driving this result and give a markedly different picture of the effects of trade on war. The fixed effects estimator indicates no effect of trade on war for the full sample as well as for the 1939-97 sample; for the 1870-1938 period, the coefficient is positive, but not significant. It is also worth noting that the years of peace variable is positive with the fixed effect estimator, implying that the longer the period of time since a particular country pair have engaged in war, the higher the likelihood of a future war between them.

These results cast doubt about the extent to which trade interdependence affects variations in the likelihood of conflict for any given individual country pair. That is, the explanatory power of trade in our war equations is entirely attributable to fitting variations across country pairs (between effects) rather than explaining variations across time for individual pairs (within effect).

In order to illustrate this point more clearly, in Table 7 we estimate the "between effects" estimator for our war equation in two different ways. In the first three columns we report the

\footnotetext{
${ }^{26}$ Another explanatory variable commonly employed in the literature is the degree of democratic similarity among country pairs. In particular, the "democratic peace" proposition hypothesizes that countries sharing similar democratic values are less likely to engage in war (Oneal and Russet, 1997, 1999).
} 
pooled logit estimates, similar to those in Table 6, but with the trade dependence ratio for each country pair replaced by the corresponding intra-pair mean (in these specifications we do not time-average the value of the any other explanatory variables in the specification) In the last three columns we report the results of estimating a cross-section relationship in which the dependent variable and all explanatory variables are time averaged over the sample period. Since the average value of war is no longer a 0-1 variable in this case, we use a simple OLS estimator (with robust errors). In almost all cases we find that differences in trade levels across pairs exert a significant, negative effect on the likelihood of conflict (the sole exception is the cross-section estimate for the 1939-97 period). This implies that country pairs with overall higher levels of trade are on average less likely to engage in conflict than those with lower trade levels.

We conclude this discussion by reporting in Table 8 the results of a panel instrumental variable regression, where we instrument for contemporaneous war with those variables found earlier to be useful in explaining the likelihood of war - the number of years since peace, major power status, alliance relationships, and distance (in addition to all of the regressors in the "second-stage" trade equation). ${ }^{27}$ For comparison, in the first column we report the corresponding fixed effect results when not instrumenting out war. Year dummies are included but are not reported in both estimations. ${ }^{28}$ The coefficient on war is slightly higher (in absolute value) in the results from the instrumental procedure (2.02 versus 1.78$)$, but all other coefficients are virtually unchanged. Thus controlling for simultaneity does not have much of an effect. A Hausman test confirms this; the hypothesis of a systematic difference between the two sets of results in Table 8 can be rejected at better than 1 percent.

In sum, our estimates of war equations imply that the level of trade interdependence may help to answer the question of which countries engage in conflict, rather than when countries engage in conflict. Trade does not appear to explain much of the time series variation in war for individual country pairs. Thus simultaneity does not appear to be a serious problem for our estimates of the effects of war and conflict on trade, particularly when controlling for fixed effects.

\footnotetext{
${ }^{27}$ We instrument out only contemporaneous war, not its lags. Note that the first stage of this procedure involves estimation of a linear probability, rather than a probit, equation for war.

${ }^{28}$ These results are virtually identical to those previously reported in the first column of Table 2 . They differ only in that the observation set is restricted to be the same as that used in the instrumental variable regression, as determined by the availability of data on our instruments.
} 


\section{Counterfactuals for World Wars I and II}

Clearly war depresses world trade both between adversaries and with neutral countries. By how much did World Wars I and II reduce aggregate world trade? In this section we answer this question through use of our estimated gravity equations.

To construct a counterfactual "normal" benchmark level for trade in the absence of war, we assume that trade for each country pair would have stayed at the same level as that in the year before the outbreak of war (1913 for WWI, 1938 for WWII), which we denote here as year $0{ }^{29}$ That is, we set $\operatorname{Trade}_{\mathrm{ijt}}^{\text {normal }}=\operatorname{Trade}_{\mathrm{ij} 0}$ for all $\mathrm{t}>0$ in the interval encompassing the contemporaneous years of war and the 10-year aftermath period over which our empirical analysis has suggested lagged effects of war may exist. With these imputed "normal" trade levels in the absence of war, we then employ our gravity model war coefficients-from column 1 in Table 5- to calculate the war-induced year-by-year reduction in trade among adversaries as well as belligerent-neutral country pairs from year to year. We can then aggregate all country pairs and compute the ratio of aggregate world trade in the presence of war to the counterfactual level in the absence of war. ${ }^{30}$

Specifically, we calculate the fractional wartime reduction in trade for each pair as ${ }^{31}$ :

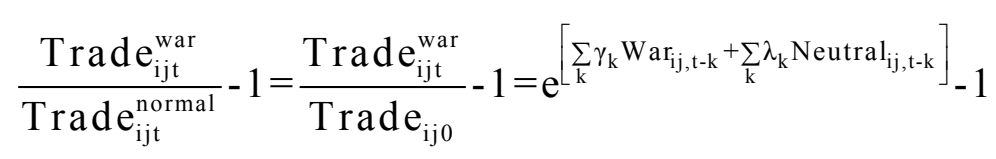

The impact of war on world trade in each year can then be computed as a weighted sum:

\footnotetext{
${ }^{29}$ We have tried other approaches to check the sensitivity of this assumption. For example, we also tried a definition of normal that is based on the trend level of trade between the first year before the war and the $10^{\text {th }}$ year after the cessation of war (i.e., 1928 for WWI, 1955 for WWII). From these endpoints, we can linearly interpolate "normal" bilateral trade levels for the years 1914-1927 and 1939-1954 for all country pairs, and use that as the counterfactual reference level of trade in the absence of war. This made negligible difference to the subsequent calculations, so we elected to use the constant level of trade as a simple benchmark for illustration.

${ }^{30}$ Note that the gravity model estimates of the effect of war on trade require that we have data for actual trade and the regressor variables for at least some country pairs while at war. However, our counterfactual approach allows us to include the trade effects of war even for pairs for whom some or all such data are missing during these war episodes. All it requires is that actual trade data exist at the beginning of the war episodes, i.e., 1913 and 1938. Moreover, by assuming that the estimated war coefficients can be applied even to pair observations not in the underlying estimation because of missing data, we can infer the effect of war on the trade of these pairs as well.

${ }^{31}$ For multi-year wars the contemporaneous effects of war for belligerents and neutrals -- $\gamma_{0}, \lambda_{0}$-- apply for years $t=1, \ldots t^{*}$, where $t^{*}$ is the last year of the war; the lagged effects kick in for the aftermath years $t^{*}+1, \ldots t^{*}+10$.
} 


$$
\frac{\operatorname{Trade}_{\mathrm{t}}^{\text {war }}}{\operatorname{Trade}^{\text {normal }}}-1=\frac{\sum_{(\mathrm{i}, \mathrm{j})}\left(\mathrm{e}^{\left[\sum_{\mathrm{k}} \gamma_{\mathrm{k}} \operatorname{War}_{\mathrm{ij}, \mathrm{t}-\mathrm{k}}+\sum_{\mathrm{k}} \lambda_{\mathrm{k}} \operatorname{Neutra}_{\mathrm{ij}, \mathrm{t}-\mathrm{k}}\right]}-1\right)\left(\operatorname{Trade}_{\mathrm{ij} 0}\right)}{\sum_{(\mathrm{i}, \mathrm{j})}\left(\operatorname{Trade}_{\mathrm{ij} 0}\right)}
$$

Although the decomposition is only approximate, we may use this formula to isolate two separate impacts, first, the reduction in world trade due to lost trade among the belligerents:

$$
\frac{\operatorname{Trade}_{\mathrm{t}}^{\text {war }}}{\operatorname{Trade}^{\text {normal }}}-1=\frac{\sum_{(\mathrm{i}, \mathrm{j})}\left(\mathrm{e}^{\left[\sum_{\mathrm{k}} \gamma_{\mathrm{k}} \mathrm{War}_{\mathrm{ij}, t-\mathrm{k}}\right]}-1\right)\left(\operatorname{Trade}_{\mathrm{ij} 0}\right)}{\sum_{(\mathrm{i}, \mathrm{j})}\left(\operatorname{Trade}_{\mathrm{ij} 0}\right)} .
$$

And, second, the reduction in world trade due to the impact of war on belligerent-neutral trade:

$$
\frac{\operatorname{Trade}_{\mathrm{t}}^{\text {war }}}{\operatorname{Trade}^{\text {normal }}}-1=\frac{\sum_{(\mathrm{i}, \mathrm{j})}\left(\mathrm{e}^{\left[\sum_{\mathrm{k}} \lambda_{\mathrm{k}} \text { Neutra }_{\mathrm{ij}, \mathrm{t}-\mathrm{k}}\right]}-1\right)\left(\operatorname{Trade}_{\mathrm{ij} 0}\right)}{\sum_{(\mathrm{i}, \mathrm{j})}\left(\operatorname{Trade}_{\mathrm{ij} 0}\right)} .
$$

Figures 2 and 3 present the results of this exercise for WWI and WWII, respectively, with the impact on total world trade shown. Panel (a) shows the destructive impact on world trade of war between adversaries. Panel (b) shows the impact of war on world trade resulting from the destruction of trade between belligerents and neutrals. A ratio less than unity implies that trade in the presence of war is less than the (imputed) trade in the absence of war. ${ }^{32}$ Dotted lines indicate 95\% confidence bands. The effects are, of course, smaller than those shown in Figure 1 since not every pair consisted of two adversaries (or a belligerent and a neutral).

We observe that:

\footnotetext{
${ }^{32}$ Note that the ratio of trade in the presence of war to counterfactual trade in the absence of war is unity by construction in the years before and after the intervals 1914-1927 and 1939-1954.
} 
o In the case WWI, war among adversaries reduced world trade by roughly $12 \%$ in 19141915 and by almost 15\% in 1916-1918; the effects then dampened monotonically. The impact on neutrals reduced world trade by an additional 5-6\% in the period 1914-18.

o In the case of WWII, war among adversaries reduced world trade by $15 \%$ in 1941 and by almost $20 \%$ in 1945 , as more countries entered the war. The impact on neutrals accounts for a fall off in trade of an additional 8-9\% during 1939-41; this effect then decays as the United States and other countries shift from neutral to belligerent status.

On the face of it these effects are potentially very large in terms of implied costs for the world as a whole, and even more so for the countries concerned. ${ }^{33}$ Cumulating a $15 \%$ loss of trade over a 5-year to 7-year wartime period, followed by a gradual recovery over the next 10 years, represents a significant and persistent economic burden. But this is somewhat conjectural: lost trade isn't lost output. So we now attempt to measure the latter.

\section{Tallying the Costs of War}

Although we find evidence suggestive of large economic losses via lost trade, we cannot easily attach a welfare measure to these losses. Moreover, it may be thought that these losses would pale in comparison to the horrific losses of life that are included in the traditional direct costs of war. In the major conflicts, when millions perished, or even in the minor ones, we hesitate to place a pecuniary value on even one lost "statistical" life. Can millions of dollars of lost trade really be compared on a balance sheet with millions of dead and wounded?

Nonetheless, to make any comparison among the different costs of war, such a cold calculus is unfortunately necessary. That said, we proceed to draw on the ideas of Goldin and Lewis (1975) who made pioneering comparisons between the cost of waging the American Civil War and the cost of alternative counterfactual schemes for settling the North-South conflict (e.g., buying out the slaves). In the Goldin and Lewis approach to valuing lost human capital, the cost of a life lost in the war was valued at the prevailing average real wage, and the cost of a wounded individual at one half of this wage. Such losses could then be amortized at some discount rate to convert the annual lost wages every year (a flow) to a one-time cost (a stock).

\footnotetext{
${ }^{33}$ Note that these calculations are based on coefficients estimated from the average effects of all wars in the sample, reported in column 1 of Table 5. The decline in trade would be even larger had we used the coefficients in the last two columns of Table 5, reflecting the estimated effects of World War I and II alone.
} 


\section{The Costs of World War I}

Table 9 presents rough calculations of the costs of World War I on this basis, using the best estimates for dead and wounded, proxy real wage levels based on Maddison's internationally comparable estimates of GDP per capita, and parameter assumptions for labor's share of output (including human capital) and the share of the population in the workforce. Specifically, we assumed that the share of output earned by labor and human capital was two thirds (cf. Mankiw, Romer, and Weil 1992), and the labor force was one half of total population (the rough 1910 average in the sample of Taylor and Williamson 1997). In this case, the percentage loss of output would be exactly equal to $4 / 3$ (2/3 divided by $1 / 2)$ times the percentage dead-equivalent population loss, if all dead are assumed to be of working age. ${ }^{34}$

As the table reports, at war's end there were 8.6 million dead and 5.4 million wounded, for a total of 16.3 million dead-equivalent lost. The losses were unevenly spread. For the Central Powers, Germany and Austria-Hungary accounted for almost half of these losses, 7 million dead equivalent. Among the Allies, France bore a heavy cost with 2.5 million, with Britain losing 1.5 million and Italy 1 million. However, judged with an eye to the scales of different countries, whether population or GDP, the relative costs looked rather different. Tiny New Zealand lost 37 thousand (of 1.1 million) by the dead-equivalent measure; populous India lost 83 thousand (of 304 million).

Applying the Goldin-Lewis metric, we find that the costs, measured as permanent equivalent flow losses to GDP, were highest on the losing side. Germany (8.5\%) and AustriaHungary (7.5\%). Alternate, disputed death counts would also assign Turkey a large cost (see the notes to the Table). France $(8.0 \%)$ bore a heavy burden, while the other Allies' costs were somewhat lower: Britain (4.4\%) and Italy (3.8\%). On a proportional basis, three U.K. dominions also paid heavily: New Zealand (4.4\%), Australia (3.7\%) and Canada (2.3\%). Bulgaria (4.9\%), Serbia (4.9\%), and Rumania (5.6\%) witnessed large human costs on a GDP basis as well. In contrast, India's massive economy barely registered a change, and the United States was also little affected. Summing over all these belligerents, we find a total flow cost to world GDP of $3.4 \%$. It is important to note that this cost was a burden primarily for the belligerent countries; since they comprised approximately $73 \%$ of world GDP, the direct human costs as a fraction of

\footnotetext{
${ }^{34}$ To a first approximation, the percentage loss of output would equal the "labor plus human capital" share (2/3) times the percentage loss of workforce, which would in turn be twice the percentage loss of population.
} 
total world GDP amounted to around 2.5\% of world GDP. ${ }^{35}$ Absent demographic data for the war dead, we treat these flow costs as permanent as a first approximation, since most of the combatants were young soldiers with their whole adult working life stretched out before them, and the discounted value of their flow incomes 30 years or more into the future are of second order importance for this type of calculation.

Now let us try to compare these direct human costs of WWI with the indirect costs arising from trade destruction using the estimates from our model. From the discussion in Section 4, there is reason to believe that the trade-related costs of war are substantial. As discussed earlier, Figures $2 \mathrm{a}$ and $2 \mathrm{~b}$ show the predicted size of "lost trade" during and after the war relative to a counterfactual "no war" scenario where trade levels are assumed to persist at their 1913 benchmark levels. Figure 2a, which shows the decline for just the belligerentbelligerent country pairs, implies that the existence of a state of war between these countries caused total world trade to fall by approximately $12-15 \%$ during each of the 5 wartime years relative to the benchmark. In Figure 2b, for belligerent-neutral country pairs, the effect of one country in each pair being at war was to reduce total world trade by a further 5-6\%. In each case, the model suggests that trade then recovered gradually over the next 10 years, before returning to its "normal" peacetime level.

Using the calculations underlying these figures for each country pair and year we can compute the trade decline for any country or set of countries as a result of war and its lagged effects. Still, lost trade is not lost income (nor lost welfare). So these loss figures are not comparable to the direct war cost measures. Can we convert lost trade into a lost output equivalent?

One way to impute the implied loss of income is by using the Frankel and Romer (1999) estimates of the partial derivative of income (or growth) with respect to trade. In our notation, their basic cross-country regression model of the level of output per capita $(\mathrm{Y} / \mathrm{N})$ takes the form:

$$
\ln \left(\frac{\mathrm{Y}}{\mathrm{N}}\right)_{i}=\alpha+2 \delta\left(\frac{\hat{\text { Trade }}}{\mathrm{Y}}\right)_{i}+\theta \mathrm{X}_{\mathrm{i}}+\eta_{\mathrm{i}}
$$

\footnotetext{
${ }^{35}$ Maddison's estimate of World GDP for his sample of 56 countries in 1913 is $\$ 2,554,075$ (in 1990 US\$).
} 
where $\mathrm{X}$ is a vector of other control variables and Trade/ $\mathrm{Y}$ is the exogenous component of the country's trade share, which is constructed from an underlying first-stage gravity model using distance and other geographic variables as exogenous explanatory regressors. ${ }^{36}$ This two-stage or instrumental variable (IV) approach allows the authors to control for the endogeneity of trade in these regressions, for without this step the OLS estimates of the coefficients are biased. The coefficient of interest to us is $\delta$, the slope of the output-trade relationship. Frankel and Romer (1999, Table 3, column 2) give an IV estimate of $\delta=1.97$ for the trade share. ${ }^{37}$

The Frankel-Romer (FR) specification is ideally suited for our purposes since, at least with respect to the model used here, we may reasonably treat war as exogenous. Though the distance between a pair of countries never changes, the state of belligerency may fluctuate. Thus, $\delta$ is the correct parameter to use in our study to capture the impact of exogenous declines in openness, or trade share, such as would be caused by wars. We should note that this formulation of the counterfactual impact deliberately holds fixed output levels in every country, thus avoiding the question as to whether war creates a boost or a drag on the domestic economy of the belligerent, an effect that would also show up in the gravity equation but which we do not seek to estimate. Our focus on the trade channel allows us to finesse the issue, which is just as well given the scarce data on real output during wars. ${ }^{38}$

We proceed to assess the permanent income loss due to war and its aftermath relative to an assumed counterfactual constant baseline level of trade corresponding to the actual trade observed in period $t=0$ prior to the start of war, here 1913 . We can estimate the fractional loss of income in country $\mathrm{i}$ at time $\mathrm{t}>0$ using a linear approximation implied by the Frankel-Romer estimated equation:

\footnotetext{
${ }^{36}$ In our notation Trade is defined as the average of exports and imports. For Frankel and Romer, it is the sum. For this reason, using our definition, a factor of 2 must be added to the trade share coefficient.

${ }^{37}$ One possible concern is whether we may safely apply the FR postwar estimates to our WWI and WWII counterfactuals. In a study of the entire twentieth century, Irwin and Terviö (2002) also find statistically significant 2SLS (IV) estimates of the coefficient that exceed the OLS estimate, on multiple cross sections, including for 1913, the start date of our counterfactual. Unfortunately, due to the units used in their study, their coefficients are not comparable in the different cross sections they studied.

${ }^{38}$ This is not to say such effects are negligible. The magnitude of endogenous GDP shocks is the subject of considerable controversy in a parallel literature; recent research suggests they might also be quite large (Hess 2003).
} 


$$
\left(\frac{\Delta \mathrm{Y}_{\mathrm{it}}}{\mathrm{Y}_{\mathrm{i} 0}}\right)=\sum_{\mathrm{j}} 2 \delta\left(\frac{\Delta \operatorname{Trade}_{\mathrm{ijt}}}{\mathrm{Y}_{\mathrm{i} 0}}\right)=\sum_{\mathrm{j}} 2 \delta\left(\frac{\operatorname{Trade}_{\mathrm{ijt}}^{\mathrm{war}}}{\operatorname{Trade}_{\mathrm{ij} 0}}-1\right)\left(\frac{\operatorname{Trade}_{\mathrm{ij} 0}}{\mathrm{Y}_{\mathrm{i} 0}}\right) .
$$

Here, as we defined it above, $\operatorname{Trade}_{\mathrm{ijt}}^{\mathrm{war}}$ is the estimated trade for the pair at time $\mathrm{t}$ under wartime conditions, while Trade $_{\mathrm{ij} 0}$ is the assumed "normal" peacetime trade level in all years (1913 for World War I). As we have discussed, the simulation also keeps GDP levels at their peacetime constant level $\left(\mathrm{Y}_{\mathrm{ij} 0}\right)$ to isolate the trade-destruction channel. Hence, drawing on our previous calculations, the implied GDP loss in country $i$ at time $t$ is:

$$
\left(\frac{\Delta \mathrm{Y}_{\mathrm{it}}}{\mathrm{Y}_{\mathrm{i} 0}}\right)=\sum_{\mathrm{j}} 2 \delta\left(\mathrm{e}^{\left[\sum_{\mathrm{k}} \gamma_{\mathrm{k}} \mathrm{War}_{\mathrm{ij}, \mathrm{t}-\mathrm{k}}+\sum_{\mathrm{k}} \lambda_{\mathrm{k}} \operatorname{Neutral}_{\mathrm{ij}, \mathrm{t}-\mathrm{k}}\right]}-1\right)\left(\frac{\operatorname{Trade}_{\mathrm{ij} 0}}{\mathrm{Y}_{\mathrm{i} 0}}\right)
$$

Denoting the set of all countries in the world as C, we next sum these GDP losses over pairs $(\mathrm{i}, \mathrm{j})$ for various (possibly time-varying) subsets of country pairs $\mathrm{V}_{\mathrm{t}} \subseteq \mathrm{C} \times \mathrm{C}$ and calculate their present value cost

$$
\left(\frac{\Delta \mathrm{Y}}{\mathrm{Y}}\right)_{\left\{\mathrm{V}_{\mathrm{t}}\right\}}=\sum_{\mathrm{t}} \sum_{(\mathrm{i}, \mathrm{j}) \in \mathrm{V}_{\mathrm{t}}} 2 \delta \beta^{\mathrm{t}}(1-\beta)\left(\mathrm{e}^{\left[\sum_{\mathrm{k}} \gamma_{\mathrm{k}} \mathrm{Waa_{ \textrm {ij } , t - \mathrm { k } } + \sum _ { \mathrm { k } } \lambda _ { \mathrm { k } } N e u t r a 1 _ { \mathrm { ij } , t - \mathrm { k } }}\right]}-1\right)\left(\frac{\operatorname{Trade}_{\mathrm{ij} 0}}{\mathrm{Y}_{\mathrm{i} 0}}\right)
$$

by cumulating the discounted flow costs over the interval including the contemporaneous and lagged years of war, where $\beta$ is the discount factor.

To implement the cost calculation for various definitions of $V_{t}$, let $B_{t}$ be the set of belligerents in the war in year $\mathrm{t}$, and let $\mathrm{N}_{\mathrm{t}}$ be the set of neutrals, that is, all remaining countries. Accordingly, we calculate

0 losses to belligerents on trade with belligerents by setting $\mathrm{V}_{\mathrm{t}}=\mathrm{B}_{\mathrm{t}} \times \mathrm{B}_{\mathrm{t}}$;

0 losses to belligerents on trade with neutrals by setting $\mathrm{V}_{\mathrm{t}}=\mathrm{B}_{\mathrm{t}} \times \mathrm{N}_{t}$;

0 losses to neutrals on trade with belligerents by setting $V_{t}=N_{t} \times B_{t}$.

0 losses on all trade by setting $\mathrm{V}_{\mathrm{t}}=\mathrm{C} \times \mathrm{C}$. 
We note that: countries may be belligerent at different times in any given war; by construction, neutral-neutral pairs experience no trade related losses; and only opposing belligerents suffer trade loss, whereas allies do not, due to the definition of the War dummy

Table 10 reports the results of this exercise, using a discount factor of $\beta=0.95$. Looking at the weighting data, we see that in WWI the belligerent nations accounted for about half of world population, three-quarters of world GDP, and $80 \%$ of world trade (counting trade both between belligerents and between belligerent and neutral countries). According to our estimation method, both belligerents and neutrals suffered large economic impacts. Lost trade was greatest for trade among belligerents, as expected, leading to a permanent flow loss of $2.28 \%$ of GDP. The decline in trade involving neutrals caused a further income loss of $0.46 \%$, for a total flow loss of $2.74 \%$ of GDP. Neutrals only suffered due to the collapse of trade with belligerents, but this was a large share of their own trade, explaining the large flow cost for them of $2.09 \%$ of GDP. On first sight it may seem odd that the small estimated impacts on neutrals seen in Figure 1 can generate such relatively large losses for neutrals $(2.09 \%)$ compared to belligerents $(2.74 \%)$, but this follows from two facts. First, not every pair of belligerents was an adversarial pair. Second, many belligerents were big countries whilst most neutrals were small countries, and (in peacetime) had a large fraction of their trade with belligerents, as the gravity model would predict. The same absolute (real) bilateral trade loss shared by any two trading partners must weigh more heavily on the smaller country in the pair, since it will dent that country's trade to GDP ratio much more, and hence have a bigger proportional impact on output via the FrankelRomer specification. ${ }^{39}$

One possible concern is whether the results are affected by using the FR model to estimate the effect of trade on output growth, rather than output levels. We answer this question by using Frankel and Romer's IV estimate of the coefficient on the trade share with the growth rate of per capita income as the dependent variable: $\delta=1.31$ (Frankel and Romer 1999, Table 4, column 10). In fact, the results turn out to be very similar either way, as shown in Figure 4. There we assume, for simplicity, a peacetime growth rate of $2 \%$ per annum, a discount rate of $5 \%$, a trade share of $10 \%$ of GDP divided equally among allies, adversaries, and neutrals, and an initial income level of 1 in period 1 (shown as 100\%). Using the example of a five-year war (comparable to a major war like WWI) we find that the FR model in levels delivers a transitory

\footnotetext{
${ }^{39}$ We assume no change in trade levels among allies and among neutrals.
} 
loss to output that is fully reversed after 10 years of peace. The model in growth rates delivers a much smaller loss, but one that is permanent. It so happens that both trajectories deliver a loss of output of about $2.5 \%$ in present discounted value. Thus, by coincidence, the exact form of the FR model does not appear to matter for our welfare cost estimates.

Compared to the human costs, also shown in Table 10, the economic costs of lost trade were large. As a group, belligerents imposed a human cost on each other equal to $1.90 \%$ of lost population, or $3.41 \%$ of lost GDP (the GDP impact is larger due to composition effects: among belligerents, it was the richer countries that had higher casualties in WWI). Moreover, there were no global negative externalities in that human costs were essentially zero for neutrals. The total cost to the world as a whole, arising from the belligerents' casualties, was a flow cost of $2.43 \%$ of GDP-just smaller than the $2.55 \%$ attributed to lost trade. Under these assumptions and metrics, the striking conclusion is that the costs of lost trade due to WWI were just about as large as the awful costs of lost human capital.

\section{The Costs of World War II}

We should not expect the same conclusion for World War II, which was a very different beast. World War I and previous wars were confined essentially to battle zones, with little attention given to civilians as targets. World War II was the first high-technology "total war" on a global scale, involving much larger losses of life, greater suffering among civilians, and much more widespread and devastating losses of economic assets (particularly physical capital). Compared to the first war, the second was a third longer in duration, encompassed about twice as many belligerent countries, touched 4 continents instead of 1 , and mobilized 110 versus 70 million into the armed services (Nesterov 1990). We should therefore expect all of its attendant direct costs to have been that much higher.

On the other hand, there is reason to question the magnitude of the indirect costs through damage to world trade. After all, there was much less trade at the beginning of World War II. Following World War I and the Great Depression, economic isolationism was rampant. By the late 1930s tariffs and quotas had become widespread. In addition, transport costs had risen

significantly in the 1920s and 1930s, and the disintegration of the gold standard had also had a significant impact on trade volumes. Compared to the low barriers and low costs of trade in 1913, the world of 1938 was much closer to autarky. Relative to world GDP, trade volumes were 
about one half what they had been in 1913, and close to their 1870 levels (Estevadeordal, Frantz, and Taylor 2003).

These concerns notwithstanding, we press ahead and repeat the exercises of Figure 2, Table 9, and Table 10 for World War II. The results are shown in Figure 3 and in Tables 11 and 12. As noted earlier, Figure 3 is qualitatively very similar to Figure 2, although the trade losses mount up a little more slowly in 1939-41 for adversaries, as the belligerency slowly spreads to include the European Lowland countries and Italy in 1940 and the United States and Japan at the very end of 1941. The trough is a little deeper in World War II, however, with almost 20\% of world trade destroyed by the adversaries.

Table 11 now includes estimates of civilian casualties in the baseline figures, since World War II involved so many killed and injured noncombatants. We should interpret these figures cautiously, as the labor content of the civilian casualties was probably less than that of military casualties, implying our methodology will exaggerate somewhat the value of civilian losses. Given the margins of error on the casualty data, however, this need not cause undue anxiety. The total dead equivalent amounted to 79.5 million by our measure, where some missing data were imputed using the plausible assumption of a stable wounded/dead ratio (Appendix Table A1 supplies the details). Without imputation, the figure falls to 46.2 million (penultimate row, Table 10), and military casualties amount to about half the total, 34.7 million (final row).

Losses for individual countries, on a population or GDP basis, are not surprising. The U.S.S.R with 31.5 million dead equivalent tops the list with a $24.8 \%$ GDP flow loss, closely followed by Yugoslavia (22.6\%) and Poland (23.5\%). Germany also suffered large losses (16.7\%), as did Hungary (10.5\%). Japan lost about $8 \%$ and its adversary China $5 \%$ (but populous China suffered an absolute loss of 19.7 million dead, compared to Japan's 4.4 million). Occupied France lost 3.3\%, Belgium 2.4\%, and Netherlands 5.5\%, but Denmark only $0.2 \%$ and Norway $0.8 \%$. Britain's loss was $1.7 \%$, less than New Zealand on a proportional basis. The United States lost $0.7 \%$ by this measure. The loss for all belligerents, as a group, was $6.6 \%$ of GDP using the full (imputed) dataset, $4.9 \%$ without imputed data, and 3.6\% for military casualties only. The latter figure may be compared with the $3.4 \%$ figure for World War I from Table 9, suggesting that it was the spread of total war off the battlefield and into civilian life that seriously escalated the level of damage to human capital in the second war. 
Table 12 compares human costs to trade costs for World War II, treating 1938 as the baseline level of trade. Computing the human loss relative to total world GDP, not just belligerents' GDP, leaves a bottom line figure of 5.43\% for the global human capital loss on a permanent flow basis. If we think the civilian component is overstated (due to its smaller labor share), the true figure might be between $4 \%$ and $5 \%$. The trade costs appear at the foot of the table and are much smaller, as expected. Adversaries cost each other 1.27\% of GDP and also paid a further $0.36 \%$ due to trade lost with neutrals, for a total loss to the belligerents of $1.64 \%$. The neutrals themselves suffered a loss in trade that we value at $1.10 \%$ of their own GDP on a flow basis. Globally, summing these figures, we arrive at an overall figure of $1.54 \%$ of GDP for the permanent flow costs of World War II.

These results, as compared with those for World War I, make sense. On a human level, World War II was about twice as costly (5.43\% in Table 11 versus $2.43 \%$ in Table 9) simply because it was bigger, longer, and deadlier. With respect to the costs of trade destruction, World War II was only just over half as costly (1.54\% in Table 11 versus $2.55 \%$ in Table 9) since, although more nations were caught up in the war, overall world trade (relative to GDP) had shrunk to about half its 1913 level by 1938.

\section{What About Other Costs of War?}

Of course, the value of lost human life is not the only cost of war. Total costs, though difficult to calculate, must also take account of the destruction of physical capital, excess military spending, looting, and many other types of loss. Yet even for wars that have been as meticulously studied as World Wars I and II, such estimates are still very rough and subject to considerable disagreement in the literature. Nonetheless, we now compare our trade related costs to the available figures, subject to this caveat, and we will argue that the trade-related costs still look quite large, and clearly so for World War I.

One of the most comprehensive studies of the total costs of World War I remains that of Bogart (1920), although it has been subject to recent criticism from Broadberry and Harrison (2005). The latter object to Bogart's calculation of human costs and prefer to use a "replacement cost" approach to figuring human capital losses. However, this tends to produce a small figure for human costs (much smaller than ours above) since the latter authors do not capture lost utility but only child rearing costs; the true cost is probably also underestimated since the gestation 
period for human capital (about 18 years) is much longer than that needed to build or purchase and install a piece of physical capital, and an appropriate discount factor should be added. Since we have already computed our own human costs above, using a broader utility type measure, we avoid these problems. We capture the lost "consumer surplus" that would have been achieved by the casualties. We also avoid the potential objection that we have biased the result in our favor (of finding a relatively high trade-related cost) by using a human capital measure that looks "too small." Instead we focus on Bogart's other measures of war costs. Granted, these too attract some objections from Broadberry and Harrison (2005), mainly due to the failure to correct expenditures for wartime inflation, since Bogart computes nominal rather than real totals. But again, for our purposes, this provides the right bias - if Bogart's costs are too high and yet our trade costs still look significant in comparison, then they would look even bigger compared to inflation-adjusted costs.

According to Bogart, what he calls the "direct" costs of World War I (excess government spending) were \$186 billion in 1913 prices (Broadberry and Harrison 2005, Table 8). Excluding lost human capital, he found the "indirect" costs (property losses, etc.) were $\$ 84$ billion. These are cumulative flows, or stock measures. For comparison we found the trade-related costs of World War I were $2.55 \%$ of world GDP on a flow basis, which equates to a stock value of $\$ 104$ billion in 1913 prices. Human costs were similarly $\$ 99$ billion. ${ }^{40}$ Adding these four figures we obtain a grand total of $\$ 473$ billion, of which trade-related costs made up $22 \%$. Thus, including the impact of lost trade would augment standard measures of the total costs of World War I by almost 30\%-a significant correction, we think.

It would be desirable to be able to replicate these calculations with at least the same (albeit limited) degree of confidence for World War II, but for the second war the extant figures appear even more fragile and subject to wider suspicion. Broadberry and Harrison (2005, table 13) report an attempt by Nesterov (1990) to apply an approach similar to Bogart. He estimated direct losses at $\$ 1,433$ billion in 1938 prices, and indirect losses (including not only property but also lost human capital, not tabulated separately) at $\$ 2,567$ billion, for a total of $\$ 4,000$ billion (a surprisingly round number). In these same units, we would calculate the stock value of trade-

\footnotetext{
${ }^{40}$ The world GDP figure of $\$ 2,726$ billion in 1990 was deflated to 1913 dollars using the US CPI of 10/133.8, and the resulting flow costs for trade and human losses were multiplied by 20 to convert the flow to a stock assuming a $5 \%$ discount rate.
} 
related costs of World War II at just $\$ 134$ billion. ${ }^{41}$ Clearly, we again see the relatively minor importance of trade-related costs in the massive conflagration of 1939-45.

\section{Conclusion}

Our work estimates the economic costs of war arising from the destruction of trade. Econometric analysis suggests that these costs are quantitatively large, statistically significant, and highly persistent. Case studies of the two world wars also demonstrate that these costs can be large (or at least of the same order of magnitude) when compared to more traditional measures of war's costs, such as loss of life.

War is hell: belligerents were aghast at the human toll they suffered as a result of their war; but, on narrow economic grounds, the losses due to trade were also of a significant magnitude and are not as widely appreciated. Wars kill trade too. Moreover, the negative externalities were huge. The belligerents wrecked the world economy not just for themselves but also for everyone else.

Our study also confronts the ongoing debate over whether the costs of war imposed on the belligerents themselves are enough to dissuade them from going to war in the first place. The liberal notion that gains from trade can support cooperation and peace is an old idea dating back at least to the fourth century, when the writer Libanius declared:

God did not bestow all products upon all parts of the earth, but distributed His gifts over different regions, to the end that men might cultivate a social relationship because one would have need of the help of another. And so $\mathrm{He}$ called commerce into being, that all men might be able to have common enjoyment of the fruits of the earth, no matter where produced. ${ }^{42}$

\footnotetext{
${ }^{41}$ Based on $1.54 \%$ of world GDP in 1938 , using a U.S. CPI correction of 14/133.8 and again multiplying by 20 to convert the flow to a stock assuming a $5 \%$ discount rate.

${ }^{42}$ Libanius, Orations (III). The hypothesis was more formally developed by philosophers such as Montesquieu and Kant, and it formed the intellectual basis of a politically liberal world view that developed in the $19^{\text {th }}$ century, most famously propounded by the statesman Richard Cobden, who declared: "I see in the Free-Trade principle that which shall act on the moral world as the principle of gravitation in the universe, drawing men together, thrusting aside the antagonism of race, and creed, and language, and uniting us in the bonds of eternal peace." Richard Cobden, Speeches on Public Policy, By Richard Cobden, M.P., edited by John Bright and J. E. Thorold Rogers (London: Macmillan \& Co., 1870).
} 
The view is pithily summarized in the epigraph from Bruce Chatwin and still finds resonance in contemporary debates, as in the works of Thomas Friedman. ${ }^{43}$

A modern literature in political science studies wars as a function of bilateral trade, but such models generally do very poorly at capturing when particular countries engage in war, although they do pick up some "between" correlation reflecting which countries "on average" engage in war. Hence, we find that time-series endogeneity is weak once fixed effects are included. Trade flows do not help us understand when pairs of countries go to war, and allowing for such reverse causality does nothing to change the large measured impact of war on trade volumes. Thus, we think it is more fruitful to focus on the causality from war to trade, and to see how large these trade-related costs of war actually are, so as to see if they might in fact plausibly offer the supposed disincentive to would be belligerents.

Given the large trade costs of war that we find, it might seem reasonable to hope that they would dissuade rational policymakers from armed conflict. But the world wars offer a disturbing counterpoint to this vision and their legacy suggests a different perspective. Perhaps other mechanisms are needed to avert war, such as multinational institutions. An economic element for such a rationale might be gleaned from this paper, given the emphasis we place on the important and neglected role of external effects. The large negative trade externalities imposed on neutrals by wars ought to have encouraged neutral countries to try to set limits to the belligerent tendencies of others. After the great wars, multilateral institutions (the League of Nations, the United Nations) held out such a promise, even if they were not entirely successful. Perhaps only thus could one hope to save the neutrals from the large negative spillovers generated by the belligerents - as well as to save the belligerents from themselves.

\footnotetext{
${ }^{43}$ Thomas Friedman, The World Is Flat: A Brief History of the Twenty-first Century (Farrar, Straus, and Giroux, 2005). Here Friedman refined his previous "Golden Arches" theory - countries with McDonald's do not fight wars - to obtain his "Dell theory": "people embedded in major global supply chains don't want to fight old-time wars any more."
} 


\section{References}

Anderson, James E., and Eric van Wincoop. 2004. Trade Costs. Journal of Economic Literature 42(3): 691-751

Anderton, Charles and John Carter. 2001. The Impact of War on Trade: An Interrupted TimeSeries Study. Journal of Peace Research 38 (4): 445-457.

Barbieri, Katherine. 1996. Economic Interdependence and Militarized Interstate Conflict, 18701985. Ph.D. dissertation, SUNY Binghampton.

Barbieri, Katherine, 2002. The Liberal Illusion: Does Trade Promote Peace? Ann Arbor, Mich.: University of Michigan Press.

Barbieri, Katherine and Jack Levy. 1999. Sleeping with the Enemy: The Impact of War on Trade. Journal of Peace Research 36: 463-479.

Barbieri, Katherine and Gerald Schneider. 1999. Globalization and Peace: Assessing New Directions in the Study of Trade and Conflict. Journal of Peace Research 36 (4): 387404.

Bergeijk, Peter van. 1994. Economic Diplomacy, Trade, and Commercial Policy: Positive and Negative Sanctions in a New World Order, Vermont: Edward Elgar.

Bertrand, Marianne, Esther Duflo, Sendhil Mullainathan. 2004. How Much Should We Trust Differences-in-Differences Estimates? Quarterly Journal of Economics 119 (1): 249-75.

Bogart, Ernest L. 1919. Direct and Indirect Costs of the Great World War. New York: Oxford University Press.

Blomberg, S. Brock, and Gregory Hess. 2004. How Much Does Violence Tax Trade? CESifo Working Paper no. 1222.

Broadberry, Steven N., and Mark Harrsion. 2005. The Economics of World War I: An Overview. In The Economics of World War I. Cambridge: Cambridge University Press.

Broadberry, Steven N, and Howlett, Peter. 1998. The United Kingdom: "Victory at All Costs." In Mark Harrison (ed.), The Economics of World War II: Six Great Powers in International Comparison. Cambridge: Cambridge University Press.

CIA World Factbook. http://www.odci.gov/cia/publications/factbook/index.html. (August 14, 2000).

Estevadeordal, Antoni, Brian Frantz, and Alan M. Taylor. 2003. The Rise and Fall of World Trade, 1870-1939. Quarterly Journal of Economics 118 (May): 359-407.

Feenstra, Robert C. 2002. Border Effects and the Gravity Equation: Consistent Methods for Estimation. Scottish Journal of Political Economy 49: 491-506.

Ferguson, Niall. 1999. The Pity of War. New York: Basic Books.

Flandreau, Marc, and Mathilde Maurel. 2001. Monetary Union, Trade Integration, and Business Cycles in 19th Century Europe: Just Do It. Discussion Paper Series no. 3087, Centre for Economic Policy Research (November).

Frankel, Jeffrey A. and David Romer. 1999. Does Trade Cause Growth? American Economic Review, 89 (3): 379-99.

Frankel, Jeffrey, Ernesto Stein, and Shang Jin Wei. 1996. Regional Trading Arrangements: Natural or Supernatural? American Economic Review 86 (May): 52-56.

Glick, Reuven, and Andrew K. Rose, 2002. Does a Currency Union Affect Trade? The Time Series Evidence. European Economic Review 46 (June): 1125-51.

Goldin, Claudia and Frank Lewis. 1975. The Economic Cost of the American Civil War: Estimates and Implications. Journal of Economic History 35 (June): 299-326. 
Hess, Gregory D. 2003. The Economic Welfare Cost of Conflict: An Empirical Assessment. CESifo Working Paper no. 852.

Irwin, Douglas A., and Marko Terviö. 2002. Does Trade Raise Income? Evidence from the Twentieth Century. Journal of International Economics 58 (October): 1-18.

Jaggers, Keith, and Ted R. Gurr. 1995. Tracking Democracy's Third Wave with the Polity III Data. Journal of Peace Research 32 (November): 469-82.

Jones, Daniel, Stuart Bremer, and J. David Singer. 1996. Militarized Interstate Disputes: 18161992. Conflict Management and Peace Science 15:163-213.

Klein, Michael W., and Jay C. Shambaugh, 2004. Fixed Exchange Rates and Trade. NBER Working Paper no. 10696, National Bureau of Economic Research.

Lemke, Douglas and William Reed. 2001. The Relevance of Politically Relevant Dyads. Journal of Conflict Resolution 45(February): 126-143.

López-Córdova, J. Ernesto, and Christopher M. Meissner. 2003. Exchange-Rate Regimes and International Trade: Evidence from the Classical Gold Standard Era. American Economic Review. Forthcoming.

Maddison 1995. Monitoring the World Economy, 1820-1992. Paris: OECD.

Maddison, Angus. 2001. The World Economy: A Millennial Perspective. Paris: OECD.

Mankiw, N. Gregory, Romer, David, Weil, David N. 1992. A Contribution to the Empirics of Economic Growth. Quarterly Journal of Economics 107: 407-37.

Mansfield, Edward D. 1994. Power, Trade, and War, Princeton: Princeton University Press.

Mansfield, Edward D., and Rachel Bronson. 1997. Alliances, Preferential Trading Arrangements, and International Trade. American Political Science Review 91(1): 94107.

Mansfield, Edward D., and J. C. Pevehouse. 2000. Trade Blocs, Trade Flows, and International Conflict. International Organization 54: 775-808.

Mansfield, Edward D. and Brian M. Pollins, eds. 2003. Economic Interdependence and International Conflict: New Perspectives on an Enduring Debate. Ann Arbor, Mich.: University of Michigan Press

Martin, Philippe, Thierry Mayer, Mathias Thoenig. 2005. Make Trade not War? University of Paris I. Photocopy.

Mitchell, Brian R. 1992. International Historical Statistics: Europe, 1750-1988. New York: Stockton Press.

Mitchell, Brian R. 1993. International Historical Statistics: The Americas, 1750-1988. New York: Stockton Press.

Mitchell, Brian R. 1998. International Historical Statistics: Africa, Asia \& Oceania, 1750-1988. New York: Stockton Press.

Morrow, James, Randolph Siverson, and Tressa Taberes. 1998. The Political Determinants of International Trade: The Major Powers, 1907-1990. American Political Science Review 92 (September): 649-61.

Morrow, James, Randolph Siverson and Tressa Tabares. 1999. Correction to: 'The Political Determinants of International Trade. American Political Science Review 93(4): 931-933.

Nesterov, L. 1990. Tsena voiny [The Price of War]. Vestnik statistiki 5: 000-000.

Obstfeld, Maurice, and Alan M. 2003. Sovereign Risk, Credibility, and the Gold Standard: 1870-1913 versus 1925-31. Economic Journal 113 (April): 1-35.

Oneal, John and Bruce Russett. 1997. The Classical Liberals were Right: Democracy, Interdependence and Conflict, 1950-1985, International Studies Quarterly 41:267-94. 
Oneal, John and Bruce Russett. 1999. Assessing the Liberal Peace with Alternative Specifications: Trade Still Reduces Conflict. Journal of Peace Research 36: 423-442.

Oneal, John and Bruce Russett. 2001. Clear and Clean: The Fixed Effects of the Liberal Peace. International Organization 55(2): 469-485.

Penubarti, Mohan and Michael Ward. 2000. Commerce and Democracy. Center for Statistics and the Social Sciences Working Paper No. 6, University of Washington.

Polachek, Solomon. 1980. Conflict and Trade. Journal of Conflict Resolution, 24:55-78.

Pollins, Brian. 1989a. Conflict, Cooperation, and Commerce: The Effect of International Political Interactions on Bilateral Trade Flows. American Journal of Political Science 33:737-761.

Pollins, Brian. 1989b. Does Trade Still Follow the Flag? American Political Science Review 83: 465-480.

Reuveny, Rafael. 2000. The Trade and Conflict Debate: A Survey of Theory, Evidence and Future Research. Peace Economics, Peace Science and Public Policy 6: 23-49.

Rose, Andrew K. 2000. One Money, One Market: The Effect of Common Currencies on Trade. Economic Policy 15 (April): 7-33.

Taylor, Alan M., and Jeffrey G. Williamson. 1997. Convergence in the Age of Mass Migration. European Review of Economic History 1 (April): 27-63.

Thursby, Jerry and Marie Thursby. 1987. Bilateral Trade Flows, the Linder Hypothesis, and Exchange Risk. Review of Economics and Statistics, 69(August): 488-95.

Urlanis, B. 1971. Wars and Population. Moscow: Progress. 
Table 1: Sample Characteristics

\begin{tabular}{|c|c|c|c|}
\hline & $1870-1997$ & $1870-1938$ & 1939-1997 \\
\hline \multicolumn{4}{|l|}{ Total } \\
\hline Pair-year observations & 251905 & 13802 & 238103 \\
\hline \# of country pairs & 11535 & 739 & 11476 \\
\hline \# countries & 172 & 50 & 171 \\
\hline \multicolumn{4}{|l|}{ War, contemporaneous } \\
\hline Pair-year observations & 206 & 59 & 147 \\
\hline \# of country pairs & 75 & 25 & 64 \\
\hline \# countries & 48 & 19 & 44 \\
\hline \multicolumn{4}{|c|}{$\begin{array}{l}\text { War, contemporaneous and } \\
\text { lagged }\end{array}$} \\
\hline Pair-year observations & 2143 & 410 & 1733 \\
\hline \# of country pairs & 338 & 72 & 296 \\
\hline \# countries & 104 & 29 & 96 \\
\hline \multicolumn{4}{|c|}{$\begin{array}{l}\text { Note: "Total" refers to pair-year observations with data on bilateral trade and GDP. "War, } \\
\text { contemporaneous" refers to country pairs at war with contemporaneous data on bilateral trade and } \\
\text { GDP. "War, contemporaneous and lagged" refers to country pair observations of war or lagged war } \\
\text { (for up to } 10 \text { years) with data on trade and GDP. }\end{array}$} \\
\hline
\end{tabular}


Table 2: Pooled Panel Gravity Estimates, 1870-1997

\begin{tabular}{|c|c|c|c|c|}
\hline \multirow[b]{2}{*}{ War } & \multicolumn{2}{|c|}{ Country Pair Fixed Effects } & \multicolumn{2}{|c|}{ Country Pair Fixed Effects } \\
\hline & $\begin{array}{c}-1.78 \\
(0.09)\end{array}$ & $* * *$ & $\begin{array}{r}-2.06 \\
(0.09)\end{array}$ & $* * *$ \\
\hline War1 & $\begin{array}{l}-1.28 \\
(0.16)\end{array}$ & $* * *$ & $\begin{array}{l}-1.49 \\
(0.16)\end{array}$ & $* * *$ \\
\hline War2 & $\begin{array}{l}-1.32 \\
(0.15)\end{array}$ & $* * *$ & $\begin{array}{l}-1.45 \\
(0.14)\end{array}$ & $* * *$ \\
\hline War3 & $\begin{array}{l}-1.12 \\
(0.13)\end{array}$ & $* * *$ & $\begin{array}{l}-1.10 \\
(0.13)\end{array}$ & $* * *$ \\
\hline War4 & $\begin{array}{l}-0.70 \\
(0.12)\end{array}$ & $* * *$ & $\begin{array}{l}-0.65 \\
(0.12)\end{array}$ & $* * *$ \\
\hline War5 & $\begin{array}{l}-0.55 \\
(0.10)\end{array}$ & $* * *$ & $\begin{array}{l}-0.50 \\
(0.10)\end{array}$ & $* * *$ \\
\hline War6 & $\begin{array}{r}-0.37 \\
(0.09)\end{array}$ & $* * *$ & $\begin{array}{l}-0.22 \\
(0.09)\end{array}$ & $* *$ \\
\hline War7 & $\begin{array}{r}-0.22 \\
(0.08)\end{array}$ & $* * *$ & $\begin{array}{r}-0.09 \\
(0.08)\end{array}$ & \\
\hline War8 & $\begin{array}{l}-0.24 \\
(0.08)\end{array}$ & $* * *$ & $\begin{array}{l}-0.15 \\
(0.08)\end{array}$ & $*$ \\
\hline War9 & $\begin{array}{l}-0.11 \\
(0.08)\end{array}$ & & $\begin{array}{l}-0.05 \\
(0.08)\end{array}$ & \\
\hline War10 & $\begin{array}{r}-0.03 \\
(0.07)\end{array}$ & & $\begin{array}{r}0.03 \\
(0.07)\end{array}$ & \\
\hline Log Distance & $-\dagger$ & & $-\dagger$ & \\
\hline Log Product Real GDPs & $\begin{array}{r}0.36 \\
(0.01)\end{array}$ & $* * *$ & $\begin{array}{r}0.05 \\
(0.01)\end{array}$ & $* * *$ \\
\hline Log Product Real GDP/capita & $\begin{array}{r}0.64 \\
(0.01)\end{array}$ & $* * *$ & $\begin{array}{r}0.81 \\
(0.01)\end{array}$ & $* * *$ \\
\hline Common Language & $-\dagger$ & & $-\dagger$ & \\
\hline Common Land Border & $-\dagger$ & & $-\dagger$ & \\
\hline Number Landlocked & $-\dagger$ & & $-\dagger$ & \\
\hline Number Islands & $-\dagger$ & & $-\dagger$ & \\
\hline Log Product Land Areas & $\begin{array}{r}0.23 \\
(0.03)\end{array}$ & $* * *$ & $\begin{array}{r}0.24 \\
(0.03)\end{array}$ & $* * *$ \\
\hline Current Colony & $\begin{array}{r}0.62 \\
(0.07)\end{array}$ & $* * *$ & $\begin{array}{r}0.70 \\
(0.07)\end{array}$ & $* * *$ \\
\hline Ever Colony & $\begin{array}{r}0.07 \\
(0.15)\end{array}$ & & $\begin{array}{r}0.13 \\
(0.16)\end{array}$ & \\
\hline Currency Union & $\begin{array}{r}0.21 \\
(0.03) \\
\end{array}$ & $* * *$ & $\begin{array}{r}0.28 \\
(0.02) \\
\end{array}$ & $* * *$ \\
\hline R-squared & 0.46 & & 0.32 & \\
\hline Number of Observations & 251902 & & 251902 & \\
\hline Number of Country Pairs & 11535 & & 11535 & \\
\hline Year Dummies & Yes & & No & \\
\hline Pair Dummies & Yes & & Yes & \\
\hline Country Dummies & No & & No & \\
\hline Avg. Effect, War-War5 & -1.12 & & -1.21 & \\
\hline
\end{tabular}

$\dagger$ variable dropped due to collinearity with country pair fixed effects.

Year dummies and constant not reported.

Standard errors in parentheses. Significance at $1 \%, 5 \%$, and $10 \%$ indicated by $* * *, * *$, and $*$, respectively. 
Table 3: Pooled Panel Gravity Estimates, 1870-1997: Alternative estimators

\begin{tabular}{|c|c|c|c|c|c|c|c|c|}
\hline \multirow[b]{2}{*}{ War } & \multicolumn{2}{|c|}{ Random Effects } & \multicolumn{2}{|c|}{ Maximum-Likelihood } & \multicolumn{2}{|c|}{ OLS, robust, cluster } & \multicolumn{2}{|c|}{ OLS, robust } \\
\hline & $\begin{array}{l}-1.79 \\
(0.09)\end{array}$ & $* * *$ & $\begin{array}{l}-1.79 \\
(0.09)\end{array}$ & $* * *$ & $\begin{array}{l}-1.96 \\
(0.27)\end{array}$ & $* * *$ & $\begin{array}{c}-18 \\
(0.18)\end{array}$ & $* * *$ \\
\hline War1 & $\begin{array}{r}-1.25 \\
(0.16)\end{array}$ & $* * *$ & $\begin{array}{l}-1.25 \\
(0.16)\end{array}$ & $* * *$ & $\begin{array}{l}-1.48 \\
(0.28)\end{array}$ & $* * *$ & $\begin{array}{r}-1.64 \\
(0.28)\end{array}$ & $* * *$ \\
\hline War2 & $\begin{array}{r}-1.27 \\
(0.15)\end{array}$ & $* * *$ & $\begin{array}{c}-1.28 \\
(0.15)\end{array}$ & $* * *$ & $\begin{array}{r}-1.32 \\
(0.25)\end{array}$ & $* * *$ & $\begin{array}{r}-1.52 \\
(0.24)\end{array}$ & $* * *$ \\
\hline War3 & $\begin{array}{r}-1.09 \\
(0.13)\end{array}$ & $* * *$ & $\begin{array}{l}-1.09 \\
(0.13)\end{array}$ & $* * *$ & $\begin{array}{l}-0.93 \\
(0.17)\end{array}$ & $* * *$ & $\begin{array}{r}-1.24 \\
(0.17)\end{array}$ & $* * *$ \\
\hline War4 & $\begin{array}{c}-0.68 \\
(0.12)\end{array}$ & $* * *$ & $\begin{array}{l}-0.68 \\
(0.12)\end{array}$ & $* * *$ & $\begin{array}{l}-0.58 \\
(0.17)\end{array}$ & $* * *$ & $\begin{array}{r}-0.79 \\
(0.16)\end{array}$ & $* * *$ \\
\hline War5 & $\begin{array}{r}-0.51 \\
(0.10)\end{array}$ & $* * *$ & $\begin{array}{l}-0.52 \\
(0.10)\end{array}$ & $* * *$ & $\begin{array}{l}-0.13 \\
(0.13)\end{array}$ & & $\begin{array}{l}-0.44 \\
(0.12)\end{array}$ & $* * *$ \\
\hline War6 & $\begin{array}{r}-0.34 \\
(0.09)\end{array}$ & $* * *$ & $\begin{array}{l}-0.34 \\
(0.09)\end{array}$ & $* * *$ & $\begin{array}{l}-0.13 \\
(0.11)\end{array}$ & & $\begin{array}{r}-0.34 \\
(0.10)\end{array}$ & $* * *$ \\
\hline War7 & $\begin{array}{r}-0.20 \\
(0.08)\end{array}$ & $* *$ & $\begin{array}{l}-0.21 \\
(0.08)\end{array}$ & $* *$ & $\begin{array}{l}-0.08 \\
(0.09)\end{array}$ & & $\begin{array}{r}-0.24 \\
(0.09)\end{array}$ & $* * *$ \\
\hline War8 & $\begin{array}{r}-0.22 \\
(0.08)\end{array}$ & $* * *$ & $\begin{array}{l}-0.22 \\
(0.08)\end{array}$ & $* * *$ & $\begin{array}{l}-0.04 \\
(0.09)\end{array}$ & & $\begin{array}{r}-0.21 \\
(0.09)\end{array}$ & $* *$ \\
\hline War9 & $\begin{array}{r}-0.10 \\
(0.08)\end{array}$ & & $\begin{array}{l}-0.10 \\
(0.08)\end{array}$ & & $\begin{array}{r}0.03 \\
(0.09)\end{array}$ & & $\begin{array}{r}-0.13 \\
(0.08)\end{array}$ & $*$ \\
\hline War10 & $\begin{array}{r}-0.02 \\
(0.07)\end{array}$ & & $\begin{array}{l}-0.02 \\
(0.07)\end{array}$ & & $\begin{array}{r}0.14 \\
(0.08)\end{array}$ & * & $\begin{array}{r}-0.04 \\
(0.08)\end{array}$ & \\
\hline Log Distance & $\begin{array}{r}-1.38 \\
(0.03)\end{array}$ & $* * *$ & $\begin{array}{l}-1.38 \\
(0.03)\end{array}$ & $* * *$ & $\begin{array}{l}-1.02 \\
(0.02)\end{array}$ & $* * *$ & $\begin{array}{l}-1.17 \\
(0.01)\end{array}$ & $* * *$ \\
\hline Log Product Real GDPs & $\begin{array}{r}0.72 \\
(0.01)\end{array}$ & $* * *$ & $\begin{array}{r}0.71 \\
(0.01)\end{array}$ & $* * *$ & $\begin{array}{r}0.87 \\
(0.01)\end{array}$ & $* * *$ & $-\dagger$ & \\
\hline Log Product Real GDP/capita & $\begin{array}{r}0.43 \\
(0.01)\end{array}$ & $* * *$ & $\begin{array}{r}0.43 \\
(0.01)\end{array}$ & $* * *$ & $\begin{array}{r}0.45 \\
(0.02)\end{array}$ & $* * *$ & $\begin{array}{r}0.11 \\
(0.01)\end{array}$ & $* * *$ \\
\hline Common Language & $\begin{array}{r}0.38 \\
(0.05)\end{array}$ & $* * *$ & $\begin{array}{r}0.38 \\
(0.05)\end{array}$ & $* * *$ & $\begin{array}{r}0.44 \\
(0.04)\end{array}$ & $* * *$ & $\begin{array}{r}0.45 \\
(0.01)\end{array}$ & $* * *$ \\
\hline Common Land Border & $\begin{array}{r}0.49 \\
(0.15)\end{array}$ & $* * *$ & $\begin{array}{r}0.50 \\
(0.15)\end{array}$ & $* * *$ & $\begin{array}{r}0.31 \\
(0.11)\end{array}$ & $* * *$ & $\begin{array}{r}0.16 \\
(0.02)\end{array}$ & $* * *$ \\
\hline Number Landlocked & $\begin{array}{r}-0.36 \\
(0.04)\end{array}$ & $* * *$ & $\begin{array}{l}-0.37 \\
(0.04)\end{array}$ & $* * *$ & $\begin{array}{l}-0.12 \\
(0.04)\end{array}$ & $* * *$ & $\begin{array}{r}2.18 \\
(1141.42)\end{array}$ & \\
\hline Number Islands & $\begin{array}{r}0.07 \\
(0.05)\end{array}$ & & $\begin{array}{r}0.07 \\
(0.05)\end{array}$ & & $\begin{array}{r}0.02 \\
(0.04)\end{array}$ & & $\begin{array}{r}1.10 \\
(1051.35)\end{array}$ & \\
\hline Log Product Land Areas & $\begin{array}{l}0.02 \\
0.01\end{array}$ & $* * *$ & $\begin{array}{r}0.03 \\
(0.01)\end{array}$ & $* * *$ & $\begin{array}{l}-0.09 \\
(0.01)\end{array}$ & $* * *$ & $\begin{array}{r}-0.34 \\
(0.03)\end{array}$ & $* * *$ \\
\hline Current Colony & $\begin{array}{r}0.58 \\
(0.07)\end{array}$ & $* * *$ & $\begin{array}{r}0.58 \\
(0.07)\end{array}$ & $* * *$ & $\begin{array}{r}0.98 \\
(0.25)\end{array}$ & $* * *$ & $\begin{array}{r}0.95 \\
(0.05)\end{array}$ & $* * *$ \\
\hline Ever Colony & $\begin{array}{r}0.97 \\
(0.12)\end{array}$ & $* * *$ & $\begin{array}{r}0.92 \\
(0.12)\end{array}$ & $* * *$ & $\begin{array}{r}1.24 \\
(0.13)\end{array}$ & $* * *$ & $\begin{array}{r}1.23 \\
(0.02)\end{array}$ & $* * *$ \\
\hline Currency Union & $\begin{array}{r}0.16 \\
(0.03) \\
\end{array}$ & $* * *$ & $\begin{array}{r}0.16 \\
(0.03) \\
\end{array}$ & $* * *$ & $\begin{array}{r}1.00 \\
(0.10) \\
\end{array}$ & $* * *$ & $\begin{array}{r}0.80 \\
(0.03) \\
\end{array}$ & $* * *$ \\
\hline R-squared & & 62 & $\mathrm{~N}$ & A. & 0.6 & & 0. & \\
\hline Number of Observations & 25 & 902 & 251 & 902 & $251 \mathrm{C}$ & & 251 & 902 \\
\hline Number of Country Pairs & & 535 & 11 & 535 & 115 & & 11 & \\
\hline Pair Dummies & & es & $\mathrm{Y}$ & es & $\mathrm{Nc}$ & & $\mathrm{N}$ & \\
\hline Country Dummies & & lo & $\mathrm{N}$ & lo & $\mathrm{N}$ & & Y & \\
\hline Avg.Effect, War-War5 & & 10 & -1 & & -1.0 & & -1 & \\
\hline
\end{tabular}


Table 4: Trade Effects of War: Subperiods, 1870-1938 and 1939-1997

\begin{tabular}{|c|c|c|c|c|c|c|c|c|c|c|}
\hline \multirow[b]{2}{*}{ War } & \multicolumn{2}{|c|}{$1870-1997$} & \multicolumn{2}{|c|}{$1870-1938$} & \multicolumn{2}{|c|}{ 1939-1997 } & \multicolumn{2}{|c|}{$\begin{array}{c}1870-1938 \\
\text { World War I } \\
\text { only }\end{array}$} & \multicolumn{2}{|c|}{$\begin{array}{c}\text { 1939-1997 } \\
\text { World War II } \\
\text { only }\end{array}$} \\
\hline & $\begin{array}{c}-1.78 \\
(0.09)\end{array}$ & $* * *$ & $\begin{array}{c}-2.09 \\
(0.10)\end{array}$ & $* * *$ & $\begin{array}{r}-1.83 \\
(0.11)\end{array}$ & $* * *$ & $\begin{array}{l}-3.02 \\
(0.12)\end{array}$ & $* * *$ & $\begin{array}{r}-2.74 \\
(0.17)\end{array}$ & $* * *$ \\
\hline War1 & $\begin{array}{c}-1.28 \\
(0.16)\end{array}$ & $* * *$ & $\begin{array}{c}-1.39 \\
(0.19)\end{array}$ & $* * *$ & $\begin{array}{c}-1.32 \\
(0.18)\end{array}$ & $* * *$ & $\begin{array}{l}-2.14 \\
(0.24)\end{array}$ & $* * *$ & $\begin{array}{c}-1.14 \\
(0.29)\end{array}$ & $* * *$ \\
\hline War2 & $\begin{array}{c}-1.32 \\
(0.15)\end{array}$ & $* * *$ & $\begin{array}{c}-0.88 \\
(0.16)\end{array}$ & $* * *$ & $\begin{array}{r}-1.55 \\
(0.17)\end{array}$ & $* * *$ & $\begin{array}{l}-1.32 \\
(0.19)\end{array}$ & $* * *$ & $\begin{array}{c}-1.88 \\
(0.26)\end{array}$ & $* * *$ \\
\hline War3 & $\begin{array}{c}-1.12 \\
(0.13)\end{array}$ & $* * *$ & $\begin{array}{r}-0.46 \\
(0.17)\end{array}$ & $* * *$ & $\begin{array}{c}-1.28 \\
(0.15)\end{array}$ & $* * *$ & $\begin{array}{l}-0.66 \\
(0.19)\end{array}$ & $* * *$ & $\begin{array}{c}-1.32 \\
(0.19)\end{array}$ & $* * *$ \\
\hline War4 & $\begin{array}{r}-0.70 \\
(0.12)\end{array}$ & $* * *$ & $\begin{array}{r}-0.34 \\
(0.15)\end{array}$ & $* *$ & $\begin{array}{r}-0.76 \\
(0.13)\end{array}$ & $* * *$ & $\begin{array}{l}-0.67 \\
(0.18)\end{array}$ & $* * *$ & $\begin{array}{c}-0.98 \\
(0.18)\end{array}$ & $* * *$ \\
\hline War5 & $\begin{array}{c}-0.55 \\
(0.10)\end{array}$ & $* * *$ & $\begin{array}{r}-0.10 \\
(0.13)\end{array}$ & & $\begin{array}{r}-0.63 \\
(0.11)\end{array}$ & $* * *$ & $\begin{array}{l}-0.20 \\
(0.16)\end{array}$ & & $\begin{array}{c}-0.62 \\
(0.13)\end{array}$ & $* * *$ \\
\hline War6 & $\begin{array}{r}-0.37 \\
(0.09)\end{array}$ & $* * *$ & $\begin{array}{r}-0.06 \\
(0.12)\end{array}$ & & $\begin{array}{c}-0.42 \\
(0.10)\end{array}$ & $* * *$ & $\begin{array}{l}-0.15 \\
(0.14)\end{array}$ & & $\begin{array}{r}-0.39 \\
(0.11)\end{array}$ & $* * *$ \\
\hline War7 & $\begin{array}{r}-0.22 \\
(0.08)\end{array}$ & $* * *$ & $\begin{array}{r}0.02 \\
(0.12)\end{array}$ & & $\begin{array}{r}-0.25 \\
(0.09)\end{array}$ & $* * *$ & $\begin{array}{l}-0.01 \\
(0.13)\end{array}$ & & $\begin{array}{c}-0.23 \\
(0.10)\end{array}$ & $* *$ \\
\hline War8 & $\begin{array}{r}-0.24 \\
(0.08)\end{array}$ & $* * *$ & $\begin{array}{r}0.04 \\
(0.11)\end{array}$ & & $\begin{array}{c}-0.28 \\
(0.09)\end{array}$ & $* * *$ & $\begin{array}{r}0.01 \\
(0.13)\end{array}$ & & $\begin{array}{r}-0.27 \\
(0.10)\end{array}$ & $* * *$ \\
\hline War9 & $\begin{array}{c}-0.11 \\
(0.08)\end{array}$ & & $\begin{array}{r}0.13 \\
(0.11)\end{array}$ & & $\begin{array}{r}-0.16 \\
(0.09)\end{array}$ & * & $\begin{array}{r}0.06 \\
(0.12)\end{array}$ & & $\begin{array}{c}-0.21 \\
(0.10)\end{array}$ & $* *$ \\
\hline War10 & $\begin{array}{r}-0.03 \\
(0.07)\end{array}$ & & $\begin{array}{r}0.11 \\
(0.10)\end{array}$ & & $\begin{array}{r}-0.07 \\
(0.08)\end{array}$ & & $\begin{array}{r}0.04 \\
(0.11)\end{array}$ & & $\begin{array}{r}-0.08 \\
(0.10)\end{array}$ & \\
\hline R-squared & 0.46 & & 0.31 & & 0.17 & & 0.31 & & 0.15 & \\
\hline Number of Observations & 25190 & & 1379 & & 23810 & & 1379 & & 2381 & \\
\hline Number of Country Pairs & 1153 & & 739 & & 1147 & & 739 & & 1147 & \\
\hline Avg. Effect, War-War5 & -1.12 & & -0.88 & & -1.2 & & -1.34 & & -1.4 & \\
\hline
\end{tabular}

Country pair fixed effect estimates. Controls not reported: distance, GDP, GDP per capita, language, land border, landlocked, islands, land area, current colony, ever colony, currency union, year dummies, and constant.

Standard errors in parentheses. Significance at $1 \%, 5 \%$, and $10 \%$ indicated by $* * *, * *$, and $*$, respectively. 
Table 5: Trade Effects of War: Effect on Neutrals Included

\begin{tabular}{|c|c|c|c|c|c|c|c|c|c|c|}
\hline \multirow[b]{2}{*}{ War } & \multicolumn{2}{|c|}{ 1870-1997 } & \multicolumn{2}{|c|}{$1870-1938$} & \multicolumn{2}{|c|}{ 1939-1997 } & \multicolumn{2}{|c|}{$\begin{array}{c}1870-1938 \\
\text { World War I } \\
\text { only }\end{array}$} & \multicolumn{2}{|c|}{$\begin{array}{c}\text { 1939-1997 } \\
\text { World War II } \\
\text { only }\end{array}$} \\
\hline & $\begin{array}{r}-1.87 \\
(0.09)\end{array}$ & $* * *$ & $\begin{array}{r}-2.12 \\
(0.10)\end{array}$ & $* * *$ & $\begin{array}{r}-1.92 \\
(0.11)\end{array}$ & $* * *$ & $\begin{array}{c}-3.29 \\
(0.13)\end{array}$ & $* * *$ & $\begin{array}{c}-3.46 \\
(0.19)\end{array}$ & $* * *$ \\
\hline War1 & $\begin{array}{r}-1.32 \\
(0.16)\end{array}$ & $* * *$ & $\begin{array}{l}-1.41 \\
(0.19)\end{array}$ & $* * *$ & $\begin{array}{r}-1.36 \\
(0.18)\end{array}$ & $* * *$ & $\begin{array}{r}-2.33 \\
(0.25)\end{array}$ & $* * *$ & $\begin{array}{l}-1.41 \\
(0.29)\end{array}$ & $* * *$ \\
\hline War2 & $\begin{array}{l}-1.35 \\
(0.15)\end{array}$ & $* * *$ & $\begin{array}{r}-0.86 \\
(0.16)\end{array}$ & $* * *$ & $\begin{array}{r}-1.58 \\
(0.17)\end{array}$ & $* * *$ & $\begin{array}{r}-1.45 \\
(0.20)\end{array}$ & $* * *$ & $\begin{array}{l}-2.14 \\
(0.27)\end{array}$ & $* * *$ \\
\hline War3 & $\begin{array}{l}-1.15 \\
(0.13)\end{array}$ & $* * *$ & $\begin{array}{r}-0.47 \\
(0.17)\end{array}$ & $* * *$ & $\begin{array}{r}-1.31 \\
(0.15)\end{array}$ & $* * *$ & $\begin{array}{r}-0.73 \\
(0.20)\end{array}$ & $* * *$ & $\begin{array}{l}-1.46 \\
(0.20)\end{array}$ & $* * *$ \\
\hline War4 & $\begin{array}{r}-0.74 \\
(0.12)\end{array}$ & $* * *$ & $\begin{array}{c}-0.38 \\
(0.15)\end{array}$ & $* *$ & $\begin{array}{r}-0.80 \\
(0.13)\end{array}$ & $* * *$ & $\begin{array}{r}-0.79 \\
(0.19)\end{array}$ & $* * *$ & $\begin{array}{c}-1.08 \\
(0.19)\end{array}$ & $* * *$ \\
\hline War5 & $\begin{array}{r}-0.57 \\
(0.10)\end{array}$ & $* * *$ & $\begin{array}{c}-0.11 \\
(0.13)\end{array}$ & & $\begin{array}{r}-0.65 \\
(0.11)\end{array}$ & $* * *$ & $\begin{array}{r}-0.27 \\
(0.16)\end{array}$ & $*$ & $\begin{array}{l}-0.75 \\
(0.13)\end{array}$ & $* * *$ \\
\hline War6 & $\begin{array}{r}-0.39 \\
(0.09)\end{array}$ & $* * *$ & $\begin{array}{r}-0.09 \\
(0.12)\end{array}$ & & $\begin{array}{r}-0.44 \\
(0.10)\end{array}$ & $* * *$ & $\begin{array}{r}-0.23 \\
(0.14)\end{array}$ & & $\begin{array}{l}-0.51 \\
(0.11)\end{array}$ & $* * *$ \\
\hline War7 & $\begin{array}{r}-0.24 \\
(0.08)\end{array}$ & $* * *$ & $\begin{array}{r}0.00 \\
(0.12)\end{array}$ & & $\begin{array}{r}-0.26 \\
(0.09)\end{array}$ & $* * *$ & $\begin{array}{r}-0.07 \\
(0.14)\end{array}$ & & $\begin{array}{l}-0.35 \\
(0.10)\end{array}$ & $* * *$ \\
\hline War8 & $\begin{array}{r}-0.24 \\
(0.08)\end{array}$ & $* * *$ & $\begin{array}{r}0.02 \\
(0.11)\end{array}$ & & $\begin{array}{c}-0.28 \\
(0.09)\end{array}$ & $* * *$ & $\begin{array}{r}-0.03 \\
(0.14)\end{array}$ & & $\begin{array}{l}-0.35 \\
(0.10)\end{array}$ & $* * *$ \\
\hline War9 & $\begin{array}{r}-0.11 \\
(0.08)\end{array}$ & & $\begin{array}{r}0.10 \\
(0.11)\end{array}$ & & $\begin{array}{r}-0.15 \\
(0.09)\end{array}$ & $*$ & $\begin{array}{r}0.00 \\
(0.12)\end{array}$ & & $\begin{array}{l}-0.26 \\
(0.10)\end{array}$ & $* *$ \\
\hline War10 & $\begin{array}{r}-0.03 \\
(0.07)\end{array}$ & & $\begin{array}{r}0.12 \\
(0.10)\end{array}$ & & $\begin{array}{r}-0.07 \\
(0.08)\end{array}$ & & $\begin{array}{r}0.05 \\
(0.12)\end{array}$ & & $\begin{array}{l}-0.12 \\
(0.10)\end{array}$ & \\
\hline Neutral & $\begin{array}{r}-0.13 \\
(0.01)\end{array}$ & $* * *$ & $\begin{array}{r}-0.04 \\
(0.03)\end{array}$ & & $\begin{array}{r}-0.12 \\
(0.01)\end{array}$ & $* * *$ & $\begin{array}{r}-0.54 \\
(0.07)\end{array}$ & $* * *$ & $\begin{array}{l}-1.06 \\
(0.11)\end{array}$ & $* * *$ \\
\hline Neutral1 & $\begin{array}{r}-0.07 \\
(0.02)\end{array}$ & $* * *$ & $\begin{array}{r}-0.02 \\
(0.04)\end{array}$ & & $\begin{array}{r}-0.07 \\
(0.02)\end{array}$ & $* * *$ & $\begin{array}{r}-0.36 \\
(0.14)\end{array}$ & $* *$ & $\begin{array}{l}-0.58 \\
(0.26)\end{array}$ & $* *$ \\
\hline Neutral2 & $\begin{array}{r}-0.04 \\
(0.02)\end{array}$ & $* *$ & $\begin{array}{r}0.07 \\
(0.04)\end{array}$ & $*$ & $\begin{array}{r}-0.04 \\
(0.02)\end{array}$ & $* *$ & $\begin{array}{r}-0.25 \\
(0.10)\end{array}$ & $* *$ & $\begin{array}{l}-0.57 \\
(0.23)\end{array}$ & $* *$ \\
\hline Neutral3 & $\begin{array}{r}-0.05 \\
(0.02)\end{array}$ & $* * *$ & $\begin{array}{r}0.00 \\
(0.04)\end{array}$ & & $\begin{array}{r}-0.04 \\
(0.02)\end{array}$ & $* *$ & $\begin{array}{r}-0.15 \\
(0.10)\end{array}$ & & $\begin{array}{l}-0.18 \\
(0.10)\end{array}$ & $*$ \\
\hline Neutral4 & $\begin{array}{r}-0.09 \\
(0.02)\end{array}$ & $* * *$ & $\begin{array}{r}-0.08 \\
(0.04)\end{array}$ & $*$ & $\begin{array}{r}-0.08 \\
(0.02)\end{array}$ & $* * *$ & $\begin{array}{r}-0.23 \\
(0.10)\end{array}$ & $* *$ & $\begin{array}{l}-0.16 \\
(0.10)\end{array}$ & \\
\hline Neutral5 & $\begin{array}{r}-0.07 \\
(0.02)\end{array}$ & $* * *$ & $\begin{array}{r}-0.03 \\
(0.04)\end{array}$ & & $\begin{array}{r}-0.07 \\
(0.02)\end{array}$ & $* * *$ & $\begin{array}{r}-0.13 \\
(0.10)\end{array}$ & & $\begin{array}{r}-0.25 \\
(0.07)\end{array}$ & $* * *$ \\
\hline Neutral6 & $\begin{array}{r}-0.09 \\
(0.02)\end{array}$ & $* * *$ & $\begin{array}{r}-0.08 \\
(0.04)\end{array}$ & $*$ & $\begin{array}{r}-0.09 \\
(0.02)\end{array}$ & $* * *$ & $\begin{array}{c}-0.18 \\
(0.09)\end{array}$ & $*$ & $\begin{array}{r}-0.27 \\
(0.07)\end{array}$ & $* * *$ \\
\hline Neutral7 & $\begin{array}{r}-0.05 \\
(0.02)\end{array}$ & $* *$ & $\begin{array}{r}-0.08 \\
(0.04)\end{array}$ & $*$ & $\begin{array}{r}-0.04 \\
(0.02)\end{array}$ & $* *$ & $\begin{array}{r}-0.12 \\
(0.09)\end{array}$ & & $\begin{array}{l}-0.24 \\
(0.06)\end{array}$ & $* * *$ \\
\hline Neutral 8 & $\begin{array}{r}0.01 \\
(0.02)\end{array}$ & & $\begin{array}{r}-0.09 \\
(0.04)\end{array}$ & $* *$ & $\begin{array}{r}0.01 \\
(0.02)\end{array}$ & & $\begin{array}{r}-0.07 \\
(0.09)\end{array}$ & & $\begin{array}{l}-0.14 \\
(0.06)\end{array}$ & $* *$ \\
\hline Neutral9 & $\begin{array}{r}0.02 \\
(0.02)\end{array}$ & & $\begin{array}{r}-0.09 \\
(0.04)\end{array}$ & $* *$ & $\begin{array}{r}0.03 \\
(0.02)\end{array}$ & & $\begin{array}{r}-0.12 \\
(0.08)\end{array}$ & & $\begin{array}{l}-0.04 \\
(0.06)\end{array}$ & \\
\hline Neutral10 & $\begin{array}{r}0.02 \\
(0.02) \\
\end{array}$ & & $\begin{array}{r}-0.01 \\
(0.04) \\
\end{array}$ & & $\begin{array}{r}0.02 \\
(0.02) \\
\end{array}$ & & $\begin{array}{r}0.01 \\
(0.08) \\
\end{array}$ & & $\begin{array}{c}-0.08 \\
(0.06) \\
\end{array}$ & \\
\hline R-squared & 0.4 & & 0.31 & & 0.16 & & 0.31 & & 0.13 & \\
\hline Number of Observations & 2519 & & 13799 & & 23810 & & 1379 & & 23810 & \\
\hline Number of Country Pairs & 115 & & 739 & & 1147 & & 739 & & 1147 & \\
\hline Average Effect, War-War5 & -1.1 & & -0.89 & & -1.2 & & -1.48 & & -1.72 & \\
\hline Average Effect, Neu-Neu5 & -0.0 & & -0.02 & & -0.0 & & -0.28 & & -0.47 & \\
\hline
\end{tabular}

Country pair fixed effect estimates. Controls not reported: distance, output, output per capita, language, land border, landlocked, islands, land area, current colony, ever colony, currency union, year dummies, and constant. Standard errors in parentheses. Significance at $1 \%, 5 \%$, and $10 \%$ indicated by $* * *, * *$, and $*$, respectively. 
Table 6: Estimates of Likelihood of War: Alternative estimators and subperiods

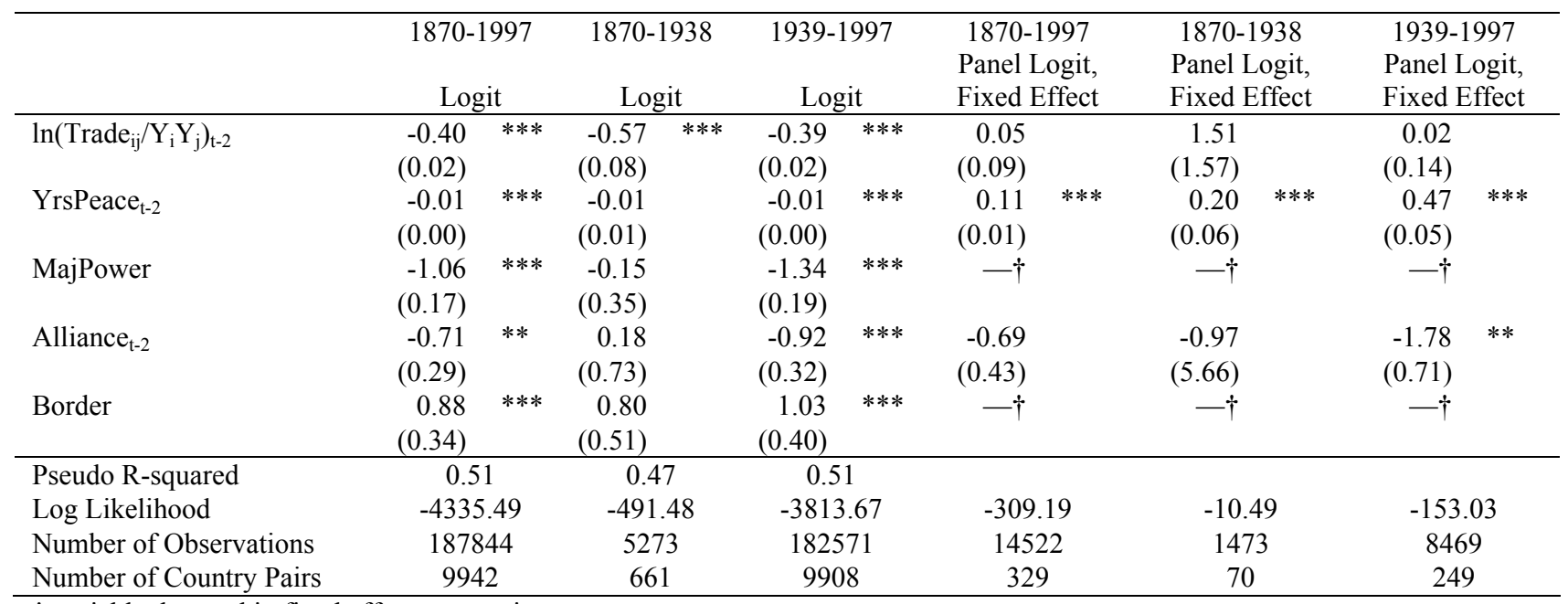

$\dagger$ variable dropped in fixed effects regression.

Year dummies and constant not reported. Estimates for YrsPeace divided by 100.

Standard errors in parentheses. Significance at $1 \%, 5 \%$, and $10 \%$ indicated by $* * *, * *$, and *, respectively.

Table 7: Estimates of Likelihood of War: Between effects

\begin{tabular}{|c|c|c|c|c|c|c|c|c|c|c|c|c|}
\hline \multirow[b]{2}{*}{ Mean of $\ln \left(\operatorname{Trade}_{\mathrm{ij}} / \mathrm{Y}_{\mathrm{i}} \mathrm{Y}_{\mathrm{j}}\right)_{\mathrm{t}-2}$} & \multicolumn{2}{|c|}{$\begin{array}{c}1870-1997 \\
\text { Logit }\end{array}$} & \multicolumn{2}{|c|}{$\begin{array}{c}1870-1938 \\
\text { Logit }\end{array}$} & \multicolumn{2}{|c|}{$\begin{array}{c}\text { 1939-1997 } \\
\text { Logit }\end{array}$} & \multicolumn{2}{|c|}{$\begin{array}{c}\text { 1870-1997 } \\
\text { OLS Cross }^{\dagger}\end{array}$} & \multicolumn{2}{|c|}{$\begin{array}{c}\text { 1870-1938 } \\
\text { OLS Cross }^{\dagger}\end{array}$} & \multicolumn{2}{|c|}{$\begin{array}{c}\text { 1939-1997 } \\
\text { OLS Cross }^{\dagger}\end{array}$} \\
\hline & $\begin{array}{r}-0.49 \\
(0.03)\end{array}$ & $* * *$ & $\begin{array}{r}-0.83 \\
(0.12)\end{array}$ & $* * *$ & $\begin{array}{l}-0.46 \\
(0.03)\end{array}$ & $* * *$ & $\begin{array}{r}-0.01 \\
(0.00)\end{array}$ & $* *$ & $\begin{array}{r}-0.10 \\
(0.03)\end{array}$ & $* * *$ & $\begin{array}{r}0.00 \\
(0.00)\end{array}$ & \\
\hline YrsPeace $_{t-2}$ & $\begin{array}{r}-0.01 \\
(0.00)\end{array}$ & $* * *$ & $\begin{array}{r}-0.01 \\
(0.01)\end{array}$ & & $\begin{array}{l}-0.01 \\
(0.00)\end{array}$ & $* * *$ & $\begin{array}{r}-0.01 \\
(0.00)\end{array}$ & $* * *$ & $\begin{array}{r}-0.05 \\
(0.00)\end{array}$ & $* * *$ & $\begin{array}{l}-0.01 \\
(0.00)\end{array}$ & $* * *$ \\
\hline MajPower & $\begin{array}{r}-0.84 \\
(0.17)\end{array}$ & $* * *$ & $\begin{array}{r}-0.08 \\
(0.38)\end{array}$ & & $\begin{array}{l}-1.13 \\
(0.18)\end{array}$ & $* * *$ & $\begin{array}{r}0.19 \\
(0.06)\end{array}$ & $* * *$ & $\begin{array}{r}0.16 \\
(0.15)\end{array}$ & & $\begin{array}{r}0.41 \\
(0.07)\end{array}$ & $* * *$ \\
\hline Alliance $_{t-2}$ & $\begin{array}{r}-0.71 \\
(0.30)\end{array}$ & $* *$ & $\begin{array}{r}0.21 \\
(0.78)\end{array}$ & & $\begin{array}{l}-0.99 \\
(0.33)\end{array}$ & $* * *$ & $\begin{array}{r}-0.36 \\
(0.06)\end{array}$ & $* * *$ & $\begin{array}{r}2.77 \\
(1.29)\end{array}$ & $* *$ & $\begin{array}{r}-0.22 \\
(0.06)\end{array}$ & $* * *$ \\
\hline Border & $\begin{array}{r}1.09 \\
(0.35)\end{array}$ & $* * *$ & $\begin{array}{r}1.28 \\
(0.60)\end{array}$ & $* *$ & $\begin{array}{r}1.19 \\
(0.41)\end{array}$ & $* * *$ & $\begin{array}{r}0.64 \\
(0.15)\end{array}$ & $* * *$ & $\begin{array}{r}0.79 \\
(0.37) \\
\end{array}$ & $* *$ & $\begin{array}{r}0.42 \\
(0.16) \\
\end{array}$ & $* * *$ \\
\hline Pseudo R-squared & 0.5 & & 0.5 & & 0.5 & & 0.13 & & 0.5 & & 0.1 & \\
\hline Log Likelihood & $-432^{\prime}$ & & -455 & & -3865 & & & & & & & \\
\hline Number of Observations & 1878 & & 527 & & 1825 & & 1371 & & 776 & & 1366 & \\
\hline Number of Country Pairs & 99 & & 661 & & 990 & & 1371 & & 776 & & 1366 & \\
\hline
\end{tabular}


Table 8: Trade Effects of War, 1870-1997: Treating War as Endogenous

\begin{tabular}{|c|c|c|c|c|}
\hline & Actual Wa & & Instrumented & War \\
\hline War & $\begin{array}{r}-1.80 \\
(0.09)\end{array}$ & $* * *$ & $\begin{array}{r}-2.02 \\
(0.67)\end{array}$ & $* * *$ \\
\hline War1 & $\begin{array}{r}-1.29 \\
(0.16)\end{array}$ & $* * *$ & $\begin{array}{r}-1.30 \\
(0.17)\end{array}$ & $* * *$ \\
\hline War2 & $\begin{array}{r}-1.32 \\
(0.15)\end{array}$ & $* * *$ & $\begin{array}{r}-1.33 \\
(0.15)\end{array}$ & $* * *$ \\
\hline War3 & $\begin{array}{l}-1.12 \\
(0.13)\end{array}$ & $* * *$ & $\begin{array}{l}-1.13 \\
(0.13)\end{array}$ & $* * *$ \\
\hline War4 & $\begin{array}{l}-0.71 \\
(0.12)\end{array}$ & $* * *$ & $\begin{array}{l}-0.72 \\
(0.12)\end{array}$ & $* * *$ \\
\hline War5 & $\begin{array}{l}-0.55 \\
(0.10)\end{array}$ & $* * *$ & $\begin{array}{l}-0.56 \\
(0.10)\end{array}$ & $* * *$ \\
\hline War6 & $\begin{array}{r}-0.37 \\
(0.09)\end{array}$ & $* * *$ & $\begin{array}{r}-0.37 \\
(0.09)\end{array}$ & $* * *$ \\
\hline War7 & $\begin{array}{l}-0.22 \\
(0.08)\end{array}$ & $* * *$ & $\begin{array}{l}-0.23 \\
(0.08)\end{array}$ & $* * *$ \\
\hline War8 & $\begin{array}{l}-0.24 \\
(0.08)\end{array}$ & $* * *$ & $\begin{array}{l}-0.24 \\
(0.08)\end{array}$ & $* * *$ \\
\hline War9 & $\begin{array}{l}-0.11 \\
(0.08)\end{array}$ & & $\begin{array}{r}-0.12 \\
(0.08)\end{array}$ & \\
\hline War10 & $\begin{array}{r}-0.03 \\
(0.07)\end{array}$ & & $\begin{array}{r}-0.03 \\
(0.07)\end{array}$ & \\
\hline Log Distance & $-\dagger$ & & $-\dagger$ & \\
\hline Log Product Real GDPs & $\begin{array}{r}0.36 \\
(0.01)\end{array}$ & $* * *$ & $\begin{array}{r}0.36 \\
(0.01)\end{array}$ & $* * *$ \\
\hline $\begin{array}{l}\text { Log Product Real GDP/capita } \\
\text { Common Language }\end{array}$ & $\begin{array}{r}0.64 \\
(0.01) \\
-+\end{array}$ & $* * *$ & $\begin{array}{r}0.64 \\
(0.01) \\
-+\end{array}$ & $* * *$ \\
\hline Common Land Border & $-\dagger$ & & $-\dagger$ & \\
\hline Number Landlocked & $-\dagger$ & & $-\dagger$ & \\
\hline Number Islands & $-\dagger$ & & $-\dagger$ & \\
\hline Log Product Land Areas & $\begin{array}{r}0.24 \\
(0.03)\end{array}$ & $* * *$ & $\begin{array}{r}0.24 \\
(0.03)\end{array}$ & $* * *$ \\
\hline Current Colony & $\begin{array}{r}0.62 \\
(0.07)\end{array}$ & $* * *$ & $\begin{array}{r}0.62 \\
(0.07)\end{array}$ & $* * *$ \\
\hline Ever Colony & $\begin{array}{r}0.07 \\
(0.15)\end{array}$ & & $\begin{array}{r}0.07 \\
(0.15)\end{array}$ & \\
\hline Currency Union & $\begin{array}{r}0.20 \\
(0.03) \\
\end{array}$ & $* * *$ & $\begin{array}{r}0.20 \\
(0.03) \\
\end{array}$ & $* * *$ \\
\hline R-squared & 0.45 & & 0.39 & \\
\hline Number of Observations & 251736 & & 251736 & \\
\hline Number of Country Pairs & 11535 & & 11535 & \\
\hline Year Dummies & Yes & & Yes & \\
\hline Pair Dummies & Yes & & Yes & \\
\hline Country Dummies & No & & No & \\
\hline Avg. Effect, War-War5 & -1.13 & & -1.18 & \\
\hline
\end{tabular}


Table 9: Human Costs of World War I

\begin{tabular}{|c|c|c|c|c|c|c|c|}
\hline \multirow[t]{2}{*}{ (b) Costs } & \multirow[b]{2}{*}{ Dead } & \multirow[b]{2}{*}{ Wounded } & \multirow[b]{2}{*}{$\begin{array}{c}\text { Dead } \\
\text { equivalent }\end{array}$} & \multirow[b]{2}{*}{$\begin{array}{l}1913 \text { Pop. } \\
\text { (mil.) }\end{array}$} & \multicolumn{2}{|c|}{ Maddison (1990\$) } & \multirow[b]{2}{*}{ Cost/GDP } \\
\hline & & & & & $\begin{array}{c}\text { Cost } \\
(\$ m i l .)\end{array}$ & $\begin{array}{c}1913 \text { GDP } \\
\text { (\$mil.) }\end{array}$ & \\
\hline France & $1,398,000$ & $2,000,000$ & $2,398,000$ & 39.8 & 11,114 & 138,665 & $8.0 \%$ \\
\hline Belgium & 13,000 & 44,686 & 35,343 & 7.7 & 198 & 32,347 & $0.6 \%$ \\
\hline Italy & 578,000 & 947,000 & $1,051,500$ & 36.6 & 3,629 & 94,845 & $3.8 \%$ \\
\hline Portugal & 7,000 & 13,751 & 13,876 & 6.0 & 23 & 7,467 & $0.3 \%$ \\
\hline Britain & 723,000 & $1,662,625$ & $1,554,313$ & 47.4 & 10,172 & 233,248 & $4.4 \%$ \\
\hline Canada & 60,383 & 155,799 & 138,283 & 7.9 & 818 & 34,916 & $2.3 \%$ \\
\hline Australia & 54,890 & 158,199 & 133,990 & 4.8 & 919 & 24,861 & $3.7 \%$ \\
\hline New Zealand & 16,500 & 41,432 & 37,216 & 1.1 & 255 & 5,781 & $4.4 \%$ \\
\hline India & 59,296 & 46,969 & 82,781 & 303.7 & 74 & 204,242 & $0.0 \%$ \\
\hline Rumania & 250,000 & 120,000 & 310,000 & 7.4 & 718 & 12,807 & $5.6 \%$ \\
\hline Serbia & 45,000 & 133,148 & 111,574 & 3.0 & 157 & 3,205 & $4.9 \%$ \\
\hline Greece & 5,000 & 21,000 & 15,500 & 2.7 & 33 & 4,344 & $0.8 \%$ \\
\hline Russia & $1,811,000$ & $1,450,000$ & $2,536,000$ & 154.0 & 5,017 & 229,143 & $2.2 \%$ \\
\hline USA & 114,000 & 205,690 & 216,845 & 97.6 & 1,529 & 517,383 & $0.3 \%$ \\
\hline Bulgaria & 88,000 & 152,390 & 164,195 & 4.4 & 335 & 6,792 & $4.9 \%$ \\
\hline Germany & $2,037,000$ & $4,207,028$ & $4,140,514$ & 65.1 & 20,089 & 237,332 & $8.5 \%$ \\
\hline Austria-Hungary & $1,100,000$ & $3,620,000$ & $2,910,000$ & 51.4 & 10,571 & 140,268 & $7.5 \%$ \\
\hline Turkey & 236,000 & 400,000 & 436,000 & 15.0 & 703 & 18,195 & $3.9 \%$ \\
\hline All belligerents & $8,596,069$ & $15,379,717$ & $16,285,928$ & 855.5 & 66,354 & $1,945,840$ & $3.4 \%$ \\
\hline
\end{tabular}

Sources: See text and notes. Dead and wounded: Military casualties only. Data from Ferguson (1999), except Canada, Australia, New Zealand and India from Bogart (1919), with authors' adjustments (see below). Incomes and populations: Maddison (2004), adjusted to 1913 land borders, using Maddison (1995, 2001), except Austria-Hungary: for Hungary the Maddison GDP per capita is $\$ 2,098$, for Austria it is $\$ 3,465$; a population-weighted average for Austria and Hungary give $\$ 2,731$. GDP is computed based on a total census population in 1910 of 51.356 million from Mitchell (1992).

Notes: Dead equivalent are dead plus one half wounded. Cost (flow cost) is calculated as real wage times dead equivalent. Real wage is proxied by real GDP per capita times labor's share (estimated as 2/3) divided by labor share of population (estimated as $1 / 2$ ). Austria-Hungary: for Hungary the Maddison GDP per capita is $\$ 2,098$, for Austria it is $\$ 3,465$; an average between Austria and Hungary gives \$2,781.5. GDP is then computed based on a total population in 1910 of 51.356 million from Mitchell (1992). Variant estimates of the death counts were considered for several countries, as follows. We found that the above Bogart-Ferguson casualty data closely match most the death counts for almost all countries in other studies, e.g., Broadberry and Harrison (2005), and the consensus is usually close to the figures presented in the original U.S. War Department study of 1924. This is not surprising since Urlanis (1971) is an important original source for these studies. However, most sources show considerable disagreement with Urlanis in the case of four countries (see: e.g., http://users.erols.com/mwhite28/warstat1.htm), where Urlanis has very high estimates of death. We cannot discount Urlanis, however, since he had special access to Soviet archives, which may lend his counts greater precision in some cases. The four countries, with corresponding ranges of alternate death toll estimates, are Belgium (low "consensus": 13,000; high, from Urlanis: 38,000), Serbia (low: 45,000-128,000; high: 278,000), Greece (low: 5,000; high: 26,000), and Turkey (low: 236,000-450,000; high: 804,000). As a sensitivity check, we recalculated costs for these 4 countries using the lowest of these ranges of estimates. Costs for these particular countries change markedly in this case, but the overall costs of the war do not change (since these are countries with small GDP weights). The table shows the results with the low estimates. 
Table 10: Economic Costs of World War I: Human versus Trade

\begin{tabular}{|c|c|c|c|}
\hline & $\begin{array}{c}\text { Belligerent } \\
\text { Countries }\end{array}$ & $\begin{array}{c}\text { Neutral } \\
\text { Countries }\end{array}$ & World \\
\hline \multicolumn{4}{|l|}{ Weighting data } \\
\hline 1913 population (million) & 855 & 916 & 1,771 \\
\hline 1913 GDP (1990\$ million) & $\$ 1,945,840$ & $\$ 780,225$ & $\$ 2,726,065$ \\
\hline 1913 trade $(1985 \$$ mil. $)$ w/allies & $\$ 44,830$ & - & $\$ 44,830$ \\
\hline 1913 trade $(1985 \$$ mil. $) \mathrm{w} /$ belligerents & $\$ 19,671$ & $\$ 16,487$ & $\$ 36,158$ \\
\hline 1913 trade $(1985 \$$ mil.) w/neutrals & $\$ 16,487$ & $\$ 3,509$ & $\$ 19,995$ \\
\hline \multirow{2}{*}{1913 trade $(1985 \$$ mil.) total } & $\$ 80,988$ & $\$ 19,995$ & $\$ 100,983$ \\
\hline & $\begin{array}{c}\text { Losses of } \\
\text { Belligerents }\end{array}$ & $\begin{array}{l}\text { Losses of } \\
\text { Neutrals }\end{array}$ & $\begin{array}{c}\text { Losses of } \\
\text { World }\end{array}$ \\
\hline Human costs & (a) & (b) & (c) \\
\hline Population loss, dead equivalent (\%) & $1.90 \%$ & - & $0.92 \%$ \\
\hline Permanent flow loss of GDP (imputed) & $3.41 \%$ & - & $2.43 \%$ \\
\hline Trade costs with Belligerents & (d) & (e) & (f) \\
\hline Permanent flow loss of trade (\%) & $4.87 \%$ & $1.61 \%$ & $1.21 \%$ \\
\hline Permanent flow loss of GDP (imputed) & $2.28 \%$ & $2.09 \%$ & $2.22 \%$ \\
\hline Trade costs with Neutrals & (g) & (h) & (i) \\
\hline Permanent flow loss of trade $(\%)$ & $1.61 \%$ & - & $1.33 \%$ \\
\hline Permanent flow loss of GDP (imputed) & $0.46 \%$ & - & $0.33 \%$ \\
\hline Trade costs, total & (j) & $(\mathrm{k})$ & (1) \\
\hline Permanent flow loss of trade (\%) & $6.48 \%$ & $1.61 \%$ & $2.54 \%$ \\
\hline Permanent flow loss of GDP (imputed) & $2.74 \%$ & $2.09 \%$ & $2.55 \%$ \\
\hline
\end{tabular}

Notes: The definition of belligerents is those countries ever involved in WWI during years 1914 to 1918 . This does not correspond exactly with the gravity-model belligerent dummy at all times: some countries may be omitted, and not all were belligerents for the entire war (e.g., the United States).

Sources: Weighting data on population and GDP from Maddison's (1995) "world" 199-country imputed totals and the corresponding data for belligerents as listed in Table 9. Trade data are from the authors' data; see text.
(a) based on Table 9 and its underlying calculations;
(b) zeroes assumed;
(c) based on a weighted average of (a) and (b);
(d) see text and Table 5, Column 1; GDP costs depend on trade share;
(e) see text and Table 5, Column 1; GDP costs depend on trade share;
(f) based on a weighted average of (d) and (e) using belligerent and neutral shares of world trade and GDP, respectively.
(g) as (d);
(h) zeroes assumed;
(i) based on a weighted average of ( $\mathrm{g}$ ) and (h) using belligerent and neutral shares of world trade and GDP, respectively.
(j) based on a sum of (d) and (g).
(k) based on a sum of (e) and (h).
(l) based on a sum of (f) and (i). 
Table 11: Human Costs of World War II

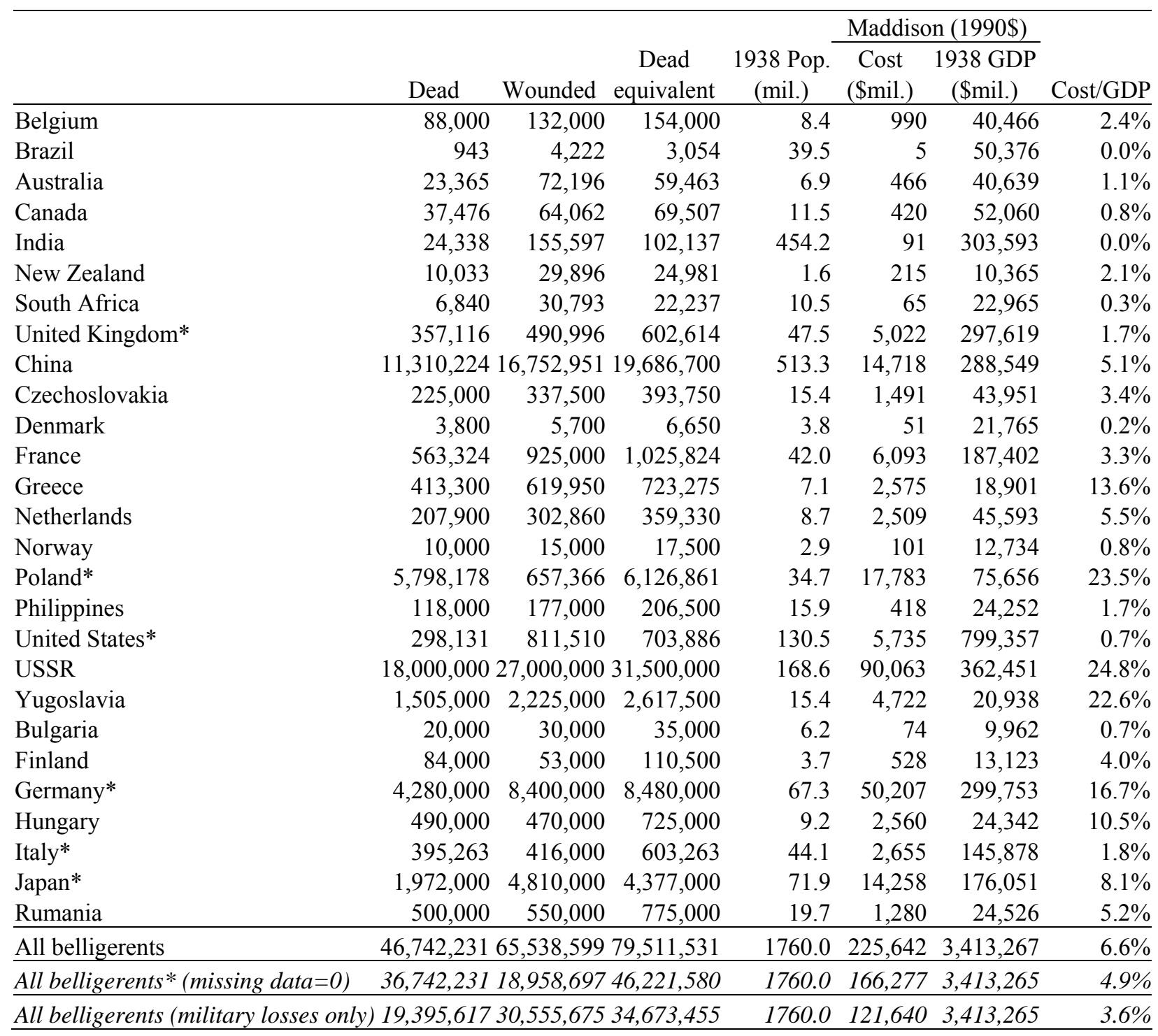

Sources: See text and notes. Dead and wounded include both military and civilian casualties; some missing data are imputed except for rows marked *. See Appendix Table A1 for details and sources. Incomes and populations are from Maddison (2004), adjusted to 1938 borders using Maddison (1995, 2001); Czechoslovakia data are 1937 values and South Africa data are interpolated using 1913 and 1950 values.

Notes: Dead equivalent are dead plus one half wounded. Cost (flow cost) is calculated as real wage times dead equivalent. Real wage is proxied by real GDP per capita times labor's share (estimated as $2 / 3$ ) divided by labor share of population (estimated as $1 / 2)$. 
Table 12: Economic Costs of World War II: Human versus Trade

\begin{tabular}{lccc}
\hline Weighting data & $\begin{array}{c}\text { Belligerent } \\
\text { Countries }\end{array}$ & $\begin{array}{c}\text { Neutral } \\
\text { Countries }\end{array}$ & World \\
1938 population (million) & 1,760 & 489 & 2,249 \\
1938 GDP (1990\$ million) & $\$ 3,413,265$ & $\$ 731,461$ & $\$ 4,144,726$ \\
& & & \\
& & - & $\$ 38,378$ \\
1938 trade (1985\$ mil.) w/allies & $\$ 38,378$ & $\$ 10,697$ & $\$ 25,999$ \\
1938 trade (1985\$ mil.) w/belligerents $(1985 \$$ mil.) w/neutrals & $\$ 10,697$ & $\$ 770$ & $\$ 11,467$ \\
& & & \\
& $\$ 63,377$ & $\$ 11,467$ & $\$ 75,844$ \\
\hline & Losses of & Losses of & Losses of \\
& Belligerents & Neutrals & World \\
\hline Human costs $1985 \$$ mil.) total & $(\mathrm{a})$ & $(\mathrm{b})$ & $(\mathrm{c})$ \\
Population loss, dead equivalent (\%) & $4.52 \%$ & - & $3.54 \%$ \\
Permanent flow loss of GDP (imputed) & $6.59 \%$ & - & $5.43 \%$ \\
\hline Trade costs with Belligerents & $(\mathrm{d})$ & $(\mathrm{e})$ & $(\mathrm{f})$ \\
Permanent flow loss of trade (\%) & $6.30 \%$ & $2.13 \%$ & $1.57 \%$ \\
Permanent flow loss of GDP (imputed) & $1.27 \%$ & $1.10 \%$ & $1.24 \%$ \\
\hline Trade costs with Neutrals & $(\mathrm{g})$ & $(\mathrm{h})$ & $(\mathrm{i})$ \\
Permanent flow loss of trade (\%) & $2.13 \%$ & - & $1.99 \%$ \\
Permanent flow loss of GDP (imputed) & $0.36 \%$ & - & $0.30 \%$ \\
\hline Trade costs, total & $(\mathrm{j})$ & $(\mathrm{k})$ & $(\mathrm{l})$ \\
Permanent flow loss of trade (\%) & $8.43 \%$ & $2.13 \%$ & $3.56 \%$ \\
Permanent flow loss of GDP (imputed) & $1.64 \%$ & $1.10 \%$ & $1.54 \%$ \\
\hline
\end{tabular}

Notes: The definition of belligerents is those countries ever involved in WWII during years 1939 to 1945 . This does not correspond exactly with the gravity-model belligerent dummy at all times: some countries may be omitted, and not all were belligerents for the entire war (e.g., the United States), and some switched sides (e.g., Italy).

Sources: Weighting data on population and GDP from Maddison's (1995) "world" 199-country imputed totals and the corresponding data for belligerents as listed in Table 11. Trade data are from the authors' data; see text.

(a) based on Table 11 and its underlying calculations;

(b) zeroes assumed;

(c) based on a weighted average of (a) and (b);

(d) see text and Table 5, Column 1; GDP costs depends on trade share;

(e) see text and Table 5 Column 1; GDP costs depends on trade share;

(f) based on a weighted average of (d) and (e) using belligerent and neutral shares of world trade and GDP, respectively.

(g) as (d);

(h) zeroes assumed;

(i) based on a weighted average of $(\mathrm{g})$ and $(\mathrm{h})$ using belligerent and neutral shares of world trade and GDP, respectively.

(j) based on a sum of (d) and $(\mathrm{g})$.

(k) based on a sum of (e) and (h).

(l) based on a sum of (f) and (i). 
Figure 1

Impact of War on Trade for a Given Country Pair

Contemporaneous Impact and Lags 1 through 10

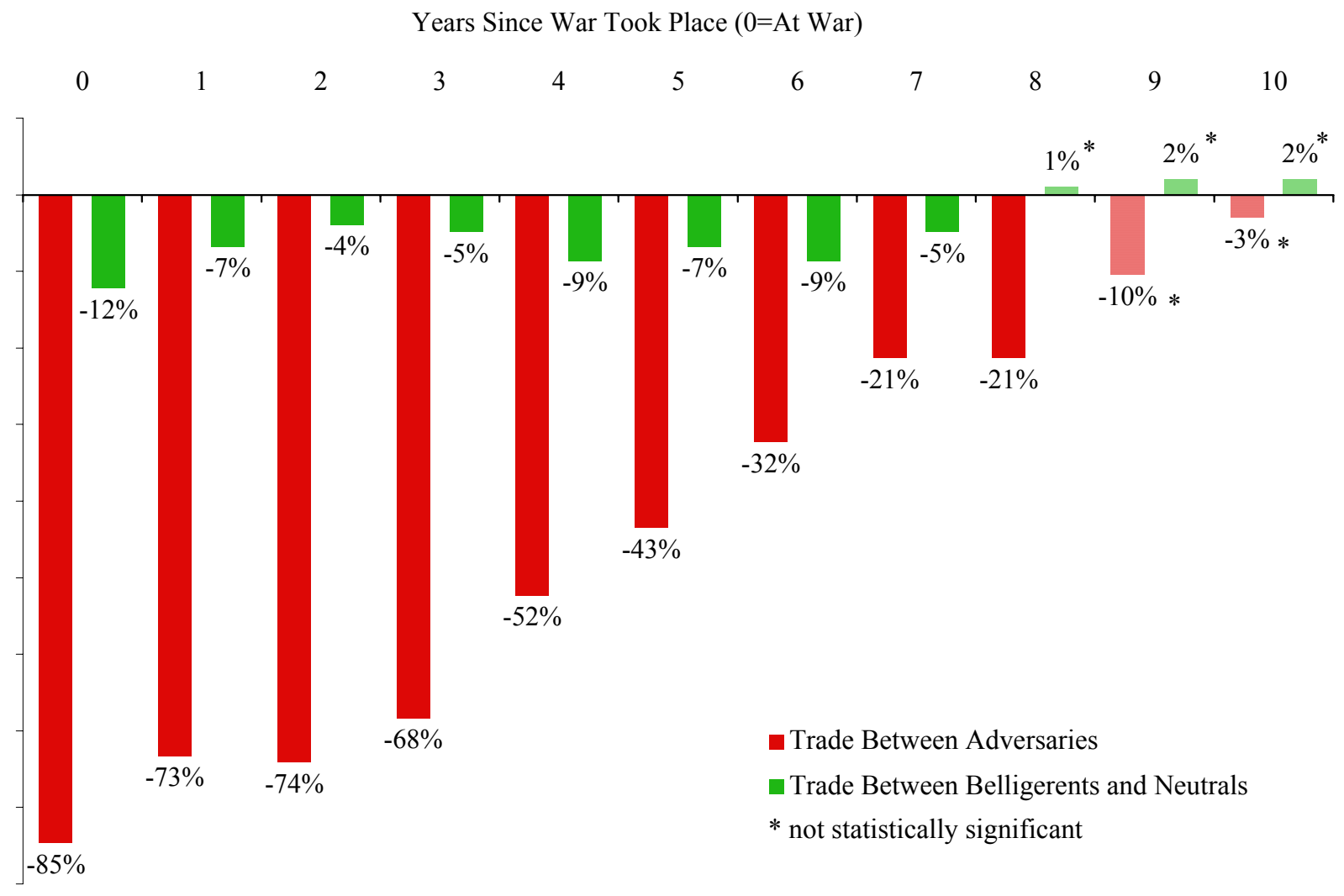

Source: Table 5, column 1. 
Figure 2

Impact of World War I on World Trade

Predicted Aggregate Wartime Trade Relative to Counterfactual Peacetime Level (1913)

(a) Adversary Country Pairs

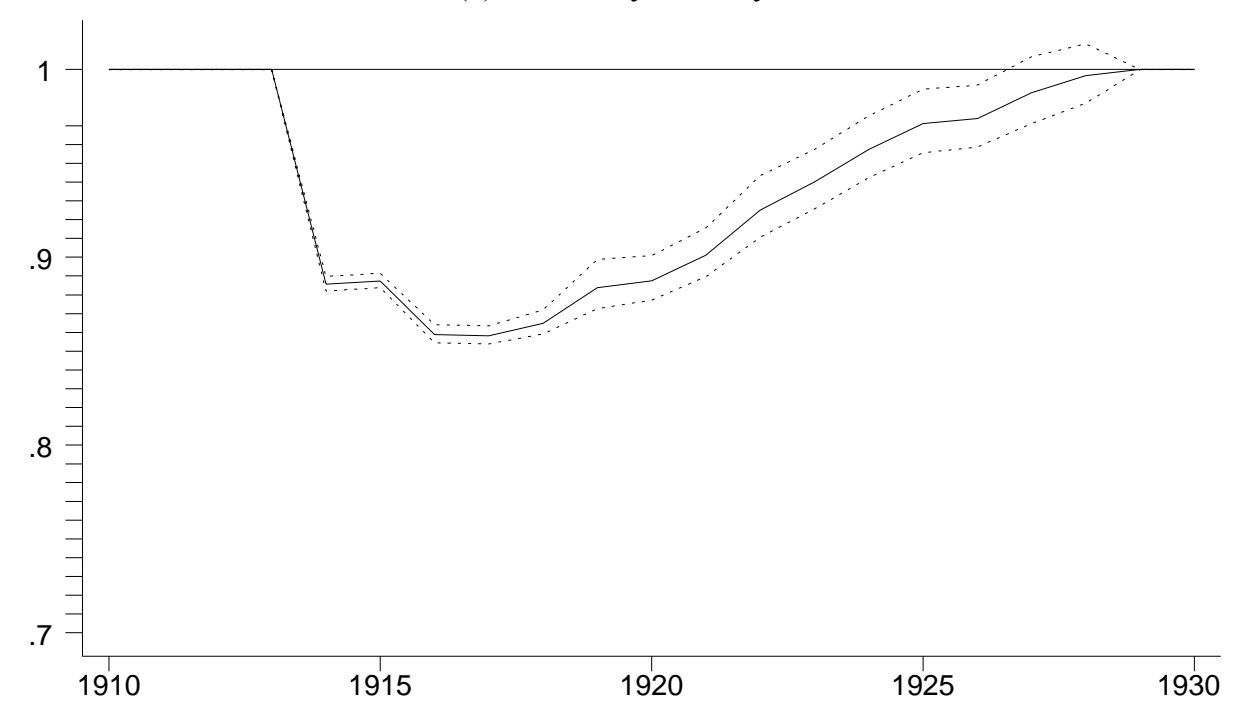

(b) Belligerent-Neutral Country Pairs

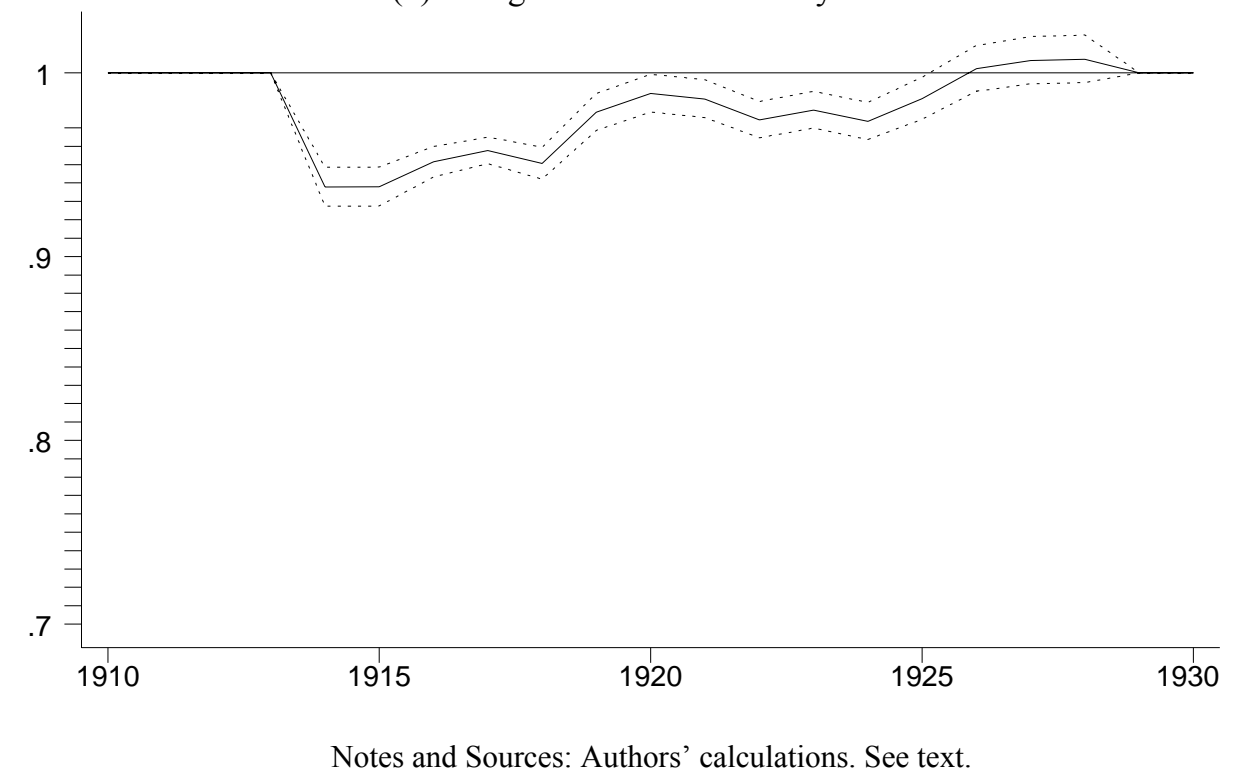


Figure 3

Impact of World War II on World Trade

Predicted Aggregate Wartime Trade Relative to Counterfactual Peacetime Level (1938)

(a) Adversary Country Pairs

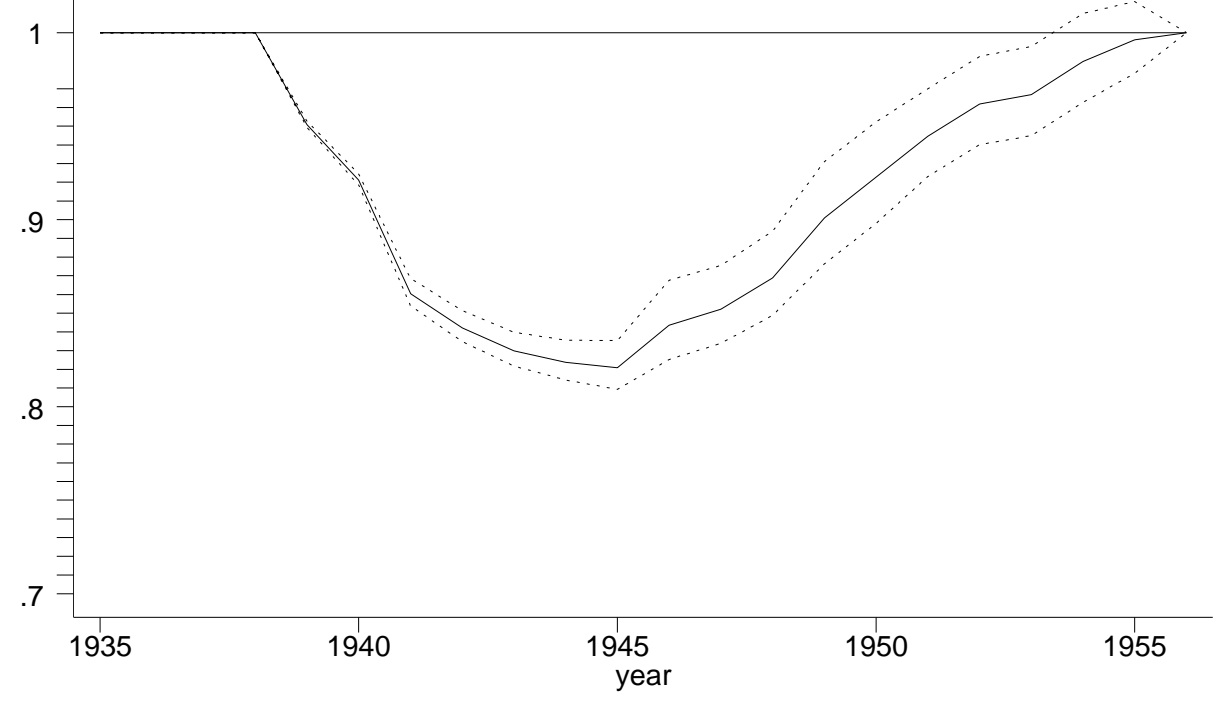

(b) Belligerent-Neutral Country Pairs

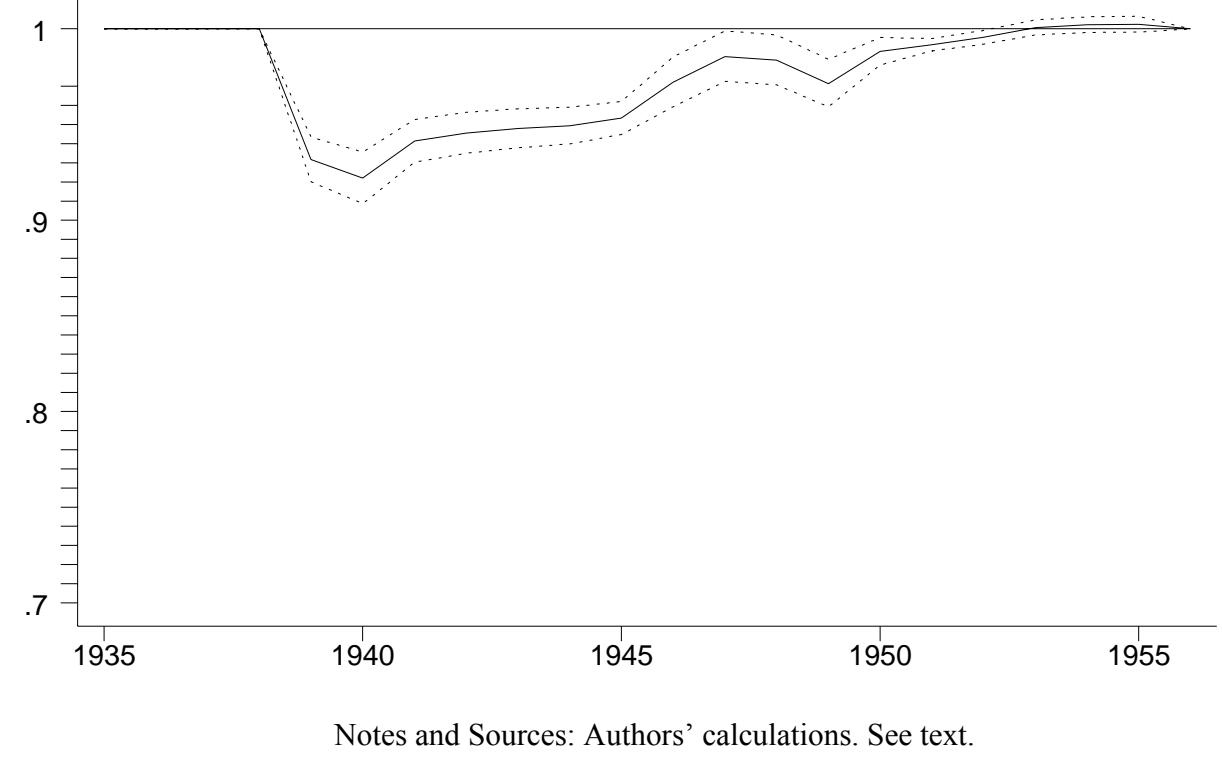


Figure 4

Impact of War on Trade and Growth Trajectory Using the Frankel-Romer (FR) Method:

Comparison of Predicted Present Discounted Value of Losses

Using the FR Model in Levels versus Growth Rates

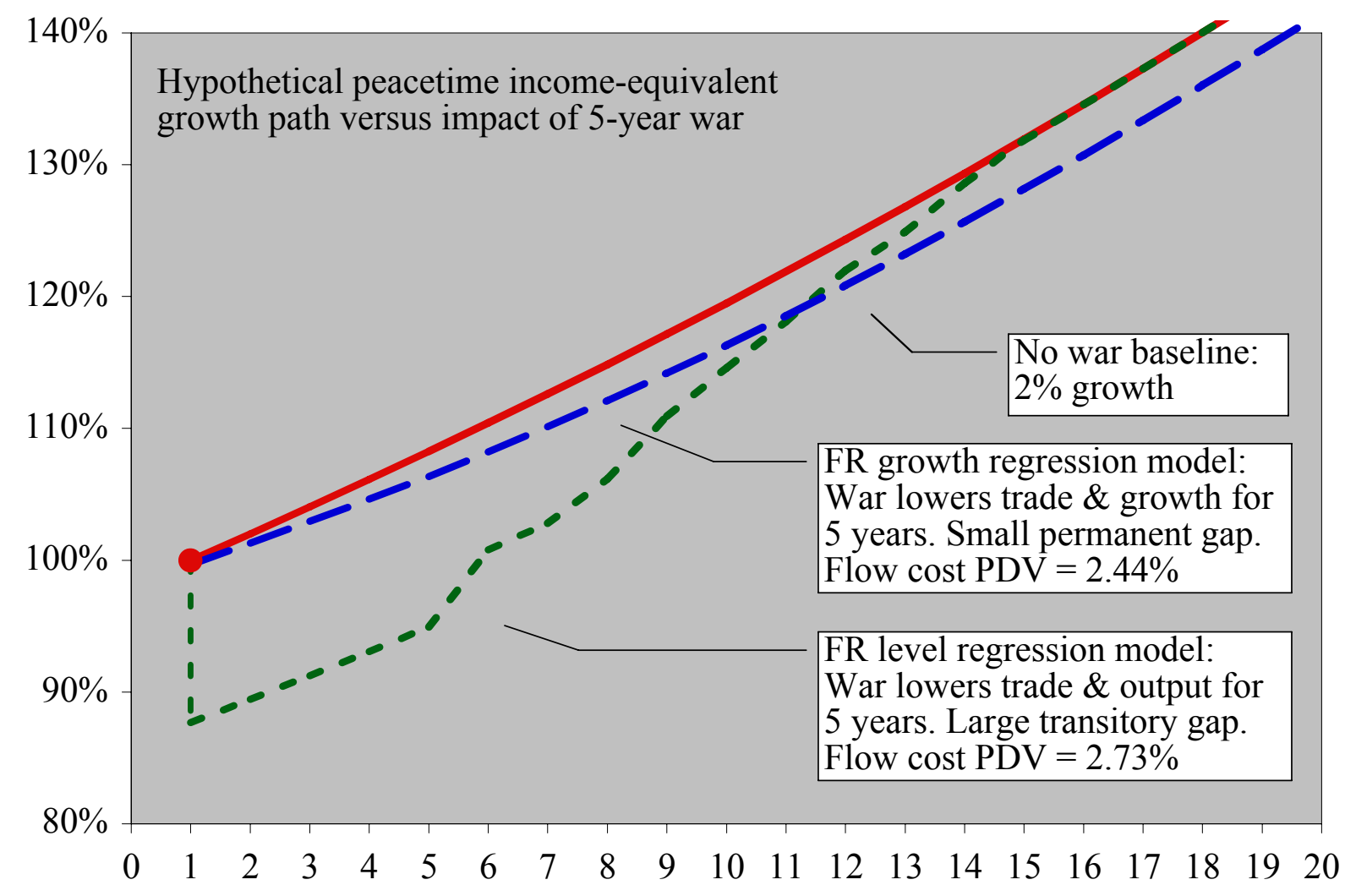




\section{Appendix Table A1: Estimating World War II Casualties}

Italic figures denote imputed data-see notes.

\begin{tabular}{|c|c|c|c|c|c|c|c|c|}
\hline Country & $\begin{array}{c}\text { Military } \\
\text { Deaths }\end{array}$ & $\begin{array}{c}\text { Military } \\
\text { Wounded or } \\
\text { Missing }\end{array}$ & $\begin{array}{c}\text { Civilian } \\
\text { Deaths Due } \\
\text { to War }\end{array}$ & $\begin{array}{c}\text { Civilian } \\
\text { Wounded or } \\
\text { Missing }\end{array}$ & Total Deaths & $\begin{array}{l}\text { Total } \\
\text { Wounded or } \\
\text { Missing }\end{array}$ & $\begin{array}{c}\text { Dead } \\
\text { Equivalent }\end{array}$ & $\begin{array}{c}\text { Dead } \\
\text { Equivalent, } \\
\text { (no imputed } \\
\text { data) }\end{array}$ \\
\hline Belgium & 12,000 & 18,000 & 76,000 & 114,000 & 88,000 & 132,000 & 154,000 & 88,000 \\
\hline Brazil & 943 & 4,222 & 0 & 0 & 943 & 4,222 & 3,054 & 3,054 \\
\hline Australia & 23,365 & 39,803 & 21,595 & 32,393 & 23,365 & 72,196 & 59,463 & 59,463 \\
\hline Canada & 37,476 & 53,174 & 7,259 & 10,888 & 37,476 & 64,062 & 69,507 & 69,507 \\
\hline India & 24,338 & 64,354 & 60,829 & 91,243 & 24,338 & 155,597 & 102,137 & 102,137 \\
\hline New Zealand & 10,033 & 19,314 & 7,055 & 10,582 & 10,033 & 29,896 & 24,981 & 24,981 \\
\hline South Africa & 6,840 & 14,363 & 10,953 & 16,430 & 6,840 & 30,793 & 22,237 & 22,237 \\
\hline U.K. & 264,443 & 277,077 & 92,673 & 213,919 & 357,116 & 490,996 & 602,614 & 602,614 \\
\hline China & $1,310,224$ & $1,752,951$ & $10,000,000$ & $15,000,000$ & $11,310,224$ & $16,752,951$ & $19,686,700$ & $2,244,324$ \\
\hline Czechoslovakia & 10,000 & 15,000 & 215,000 & 322,500 & 225,000 & 337,500 & 393,750 & 225,000 \\
\hline Denmark & 1,800 & 2,700 & 2,000 & 3,000 & 3,800 & 5,700 & 6,650 & 3,800 \\
\hline France & 213,324 & 400,000 & 350,000 & 525,000 & 563,324 & 925,000 & $1,025,824$ & 763,324 \\
\hline Greece & 88,300 & 132,450 & 325,000 & 487,500 & 413,300 & 619,950 & 723,275 & 413,300 \\
\hline Netherlands & 7,900 & 2,860 & 200,000 & 300,000 & 207,900 & 302,860 & 359,330 & 209,330 \\
\hline Norway & 3,000 & 4,500 & 7,000 & 10,500 & 10,000 & 15,000 & 17,500 & 10,000 \\
\hline Poland & 123,178 & 236,606 & $5,675,000$ & 420,760 & $5,798,178$ & 657,366 & $6,126,861$ & $6,126,861$ \\
\hline Philippines & 27,000 & 40,500 & 91,000 & 136,500 & 118,000 & 177,000 & 206,500 & 118,000 \\
\hline United States & 292,131 & 671,801 & 6,000 & 139,709 & 298,131 & 811,510 & 703,886 & 703,886 \\
\hline U.S.S.R. & $11,000,000$ & $16,500,000$ & $7,000,000$ & $10,500,000$ & $18,000,000$ & $27,000,000$ & $31,500,000$ & $18,000,000$ \\
\hline Yugoslavia & 305,000 & 425,000 & $1,200,000$ & $1,800,000$ & $1,505,000$ & $2,225,000$ & $2,617,500$ & $1,717,500$ \\
\hline Bulgaria & 10,000 & 15,000 & 10,000 & 15,000 & 20,000 & 30,000 & 35,000 & 20,000 \\
\hline Finland & 82,000 & 50,000 & 2,000 & 3,000 & 84,000 & 53,000 & 110,500 & 109,000 \\
\hline Germany & $3,500,000$ & $5,000,000$ & 780,000 & $3,400,000$ & $4,280,000$ & $8,400,000$ & $8,480,000$ & $8,480,000$ \\
\hline Hungary & 200,000 & 300,000 & 290,000 & 170,000 & 490,000 & 470,000 & 725,000 & 575,000 \\
\hline Italy & 242,322 & 66,000 & 152,941 & 350,000 & 395,263 & 416,000 & 603,263 & 603,263 \\
\hline Japan & $1,300,000$ & $4,000,000$ & 672,000 & 810,000 & $1,972,000$ & $4,810,000$ & $4,377,000$ & $4,377,000$ \\
\hline Romania & 300,000 & 450,000 & 200,000 & 100,000 & 500,000 & 550,000 & 775,000 & 550,000 \\
\hline Totals & $19,395,617$ & $30,555,675$ & $27,454,305$ & $34,982,924$ & $46,742,231$ & $65,538,599$ & $79,511,531$ & $46,221,580$ \\
\hline
\end{tabular}

Sources: Casualty data were taken from http:/www.worldwar2database.com/html/frame4.htm, with supplementary data taken from http://users.erols.com/mwhite28/ww2stats.htm.

Notes on Imputed Data: As a preliminary step, missing data for dead or wounded (civilians and military) were imputed by four methods: 1 . All missing data set to zero; 2 . Assume that for each country the number of wounded equaled 1.5 times the number of dead; 3. Assume that the proportion of wounded to dead for countries with missing data was the same as for those with data. For method 3, the following regression was run: WOUNDED $=a+b^{*} \mathrm{DEAD}$. For military casualties we found: 17 observations, $a=56,207(t=0.38)$ and $b=1.57(t=10.33), R^{2}=.88$. For civilian casualties there were too few observations (7) so the regressions produced insignificant estimates. Thus, the regression in method 3 justifies the rule of thumb used in method 2 . In this table, we show two counts based on methods 1 and 2, with the same rule of thumb applied to both civilian and military casualties.

Other Notes: Germany total includes Austrian casualties. According to some sources Austrian military deaths were 280,000 and military wounded were 350,000 , which would be $8 \%$ and $7 \%$ of the combined Austrian/German total, respectively. USSR total does not include an estimated 2 to 2.5 million civilians who died fleeing the Red Army during the Soviet invasion and expulsion from today's Western Poland and Czechoslovakia. China civilian deaths are very rough estimates. It is very doubtful that civilian deaths were zero under the Japanese occupation. One website mentions an estimate of 22,000,000 civilian deaths which is of "doubtful accuracy"; another has an implausibly low figure of 115,000. Furthermore, the military casualties are only those of the Chinese Nationalists and do not include those of the Communists. Another source estimates 11 million civilian dead due to Japanese occupations in Asia, although this includes countries other than China, e.g. Burma. Based on the latter figure we make a rough estimate of 10 million civilian dead in China. For this reason, our 5\% GDP loss for China should be considered a very rough upper bound. Poland's figures are subject to disagreement; our figures may be low; Bullock estimates military deaths at 850,000 . 


\section{Data Appendix}

This appendix provides a more detailed description of the source and construction of the data for trade, real GDP, GDP per capita, and land area. Details for all other variables are contained in the text.

\section{Bilateral Trade}

As discussed in the text, trade data for the period 1948-1997 were constructed from the IMF's Direction of Trade (DoT). These data are essentially the same as in Glick and Rose (2002); the data set is obtainable from http://faculty.haas.berkeley.edu/arose/RecRes.htm\#Software. The average value of bilateral trade between each pair of countries is created by averaging all of the possible trade values potentially available (exports from $i$ to $j$, exports from $j$ to $i$, imports into $i$ from $j$, imports into $j$ from $i$ ). Observations where all four figures have a zero or missing value are dropped from the sample.

The primary source of trade data for 1870-1947 is Barbieri (1996); her International Trade Dataset Version 1.1 can be obtained from http://pss/la.psu.edu/trd data.htm. Since her data measure bilateral trade as the sum of exports and imports between each country pair (imports into $\mathrm{i}$ into $\mathrm{j}$ and into $\mathrm{j}$ from i) exports), these figures are divided by two to create an average value of trade. When Barbieri data are unavailable, bilateral export and import data from Mitchell $(1992,1993,1998)$ for selected countries with their main trading partners are used. As with the DoT trade data used for the 1948-97 period, bilateral trade for each country pair is constructed from the Mitchell data by averaging all of the possible trade values potentially available. Remaining data gaps are filled where possible from López-Córdova and Meissner (2003).

The Barbieri trade data are expressed in millions of current U.S. dollars. López-Córdova and Meissner's trade are expressed in real 1990 U.S. dollars and were converted into nominal dollar terms using the U.S. consumer price index. The Mitchell data, which are expressed in current local currency terms, were converted into current dollar with the official exchange rate series from Global Financial Data (GFD), with exceptions noted below.

Argentina: Official rate from Mitchell (1993) is used through 1910. Data from 1911 on comes from Gerardo della Paolera, Alan M. Taylor and Carlos G. Bózzoli, "Historical Statistics," in della Paolera and Taylor, eds., A New Economic History of Argentina (Cambridge: Cambridge University Press, 2003).

Bulgaria: French Franc rate is used while Bulgaria was in the Latin Monetary Union (1880-1898, 1906-1911). An average of the 1898 and 1906 exchange rates is used for the intervening years. The 1911 rate is used for 1912 and 1913. The official Bulgarian Lev rate from GFD is used from 1920 onward.

Chile: For all years, the data comes from Juan Braun et al., "Economía Chilena 1810-1995: Estadísticas Históricas," Documento de Trabajo no. 187, Pontificia Universidad Católica de Chile, Instituto de Economía (Enero), Santiago (January 2000).

China: Trade figures for 1905-1932 in Mitchell (1998) converted from Haikwan tael into dollars using exchange rate from GFD. Figures for 1933-1938 converted into yuan at exchange rate of 1 tael = 0.72 yuan, and the yuan/dollar exchange rate from GFD then used for conversion into dollars.

Colombia: Exchange rate implicit from gold content from GFD used while Colombia was on gold standard (1871-1885, 1907-1913). For the years 1886 through 1906, we used the average of the 1885 and 1907 exchange rates; for the years 1914-1918 we used the average of the 1913 and 1919 exchange rates. The peso exchange rate from GFD was used from 1919 on.

Ghana: U.K. Pound exchange rate is used.

Greece: French Franc rate from GFD is used while Greece was in the Latin Monetary Union (1870-1876). Exchange rate figures for 1880-89 come from Michael Bordo. Figures for 1901-1945 are from GFD; the DOT rate for 1948 is used for 1946 and 1947.

Romania: French Franc rate from GFD was used while Romania was in the Latin Monetary Union (until 1914).

Serbia: French Franc rate from GFD used 
Uruguay: Data for 1885-. comes from GFD; the exchange rate for the years 1874-1884 is set equal to the 1885 rate.

Lastly, exchange rate data from the DoT for 1948 is used for 1946 and 1947 for the following countries: Belgium, Brazil, Canada, Czechoslovakia, Egypt, South Africa, Switzerland, Turkey.

Occasionally missing Barbieri observations are left unfilled even when data from Mitchell or López-Córdova and Meissner are available, because the data do not align well. Furthermore, in a limited number of instances the Barbieri observations were replaced ("overwritten") with data from Mitchell or López-Córdova and Meissner, due to apparent inconsistencies in Barbieri's figures. A list of these instances is available upon request. After data from the various sources for the 1870-1947 period were merged, the pre-1948 dataset is converted into 1985 dollars using the U.S. CPI index and then spliced together with the 1948-1997 data.

\section{GDP and GDP per capita}

As discussed in the text, real GDP and GDP per capita data (in constant 1985 dollars) for the 1948-97 period are obtained from the World Bank's World Development Indicators, the Penn World Table (PWT) Mark 5.6, Maddison (1995; 2001), and from the IMF's International Financial Statistics. These data are essentially the same as in Glick and Rose (2002), with the general exception that we use Maddison data to fill in observations for 1948 and 1949.

For the 1870-1947 period the data primarily come from Maddison $(1995 ; 2001)$ and are supplemented by information from Mitchell $(1992,1993,1998)$ and individual country sources, as described below. In general, real GDP data in national currency units from the supplementary sources are converted first into the real 1990 dollar terms reported by Maddison using the ratio of figures for overlapping year(s). GDP per capita is then calculated using population series implicit in the supplementary source's GDP and GDP per capita data. After adjusting for border changes (see below) and using the U.S. CPI to put into 1985 dollar terms, the 1870-1947 series are then linked to the 19481997 series using the average ratio of overlapping observations for 1948-1952 (the availability of Maddison data beyond 1948 allows this overlap).

Further details of the use of supplementary data sources is provided below:

Argentina: Figures for 1875-1899 are taken from Gerardo della Paolera, Alan M. Taylor, and Carlos G. Bózzoli, "Historical Statistics", in della Paolera and Taylor, eds., A New Economic History of Argentina (Cambridge: Cambridge University Press, 2003).

Austria-Hungary: GDP and GDP per capital figures for 1870-1913 come from Max-Stephan Schulze, "Patterns of Growth and Stagnation in the Late Nineteenth-Century Hapsburg Economy," European Review of Economic History 4:3 (2000). Maddison provides GDP data for Austria and Hungary separately for 1913 within their 1990 borders. These data points were scaled up by the ratio of each country's population within 1913 borders to its population within 1990 borders and then added together to give a Madison-based GDP estimate for Austria-Hungary in 1913. The Schulz GDP series was then rescaled by its ratio in 1913 to this Maddison figure. GDP for 1914-1917 were imputed from the (real) GDP figures for Austria within its 1990 borders in Maddison, scaled up by the ratio of Austria Hungary's GDP to Austria's GDP in 1913. Real GDP per capita was computed using the population series implicit in Schulze's data for 1870-1913; for 1914-1917, we rescaled Maddison's population data for Austria (within its 1990 border) by the ratio of Schulze's population figure in 1913 to Maddison's figure for Austria within its 1913 border

Brazil: Figures for 1880-1899 come from Michael Bordo and Hugh Rockoff, "The Gold Standard as a 'Good Housekeeping Seal of Approval,"' NBER Working Paper no. 5340 (November 1996).

Chile: Figures for 1870-1899 are taken from Juan Braun et al., "Economía Chilena 1810-1995: Estadísticas Históricas," Documento de Trabajo no. 187, Pontificia Universidad Católica de Chile, Instituto de Economía (Enero), Santiago (January 2000). 
Cuba: Figures for 1903-1949 come from Mitchell (1993), where data on GDP (pp. 750, 755) and population (p. 58) are presented. Since the Cuban peso is pegged one to one to the U.S. dollar, the U.S. price deflator is used to convert Mitchell's peso series into 1990 dollars.

Ecuador: Figures for 1939-1954 come from Mitchell (1993), which provides data for GDP (p. 765) and population (p. 58).

Egypt: GDP data for 1886-1945 are taken from Tarik M. Yousef, "Egypt's Growth Record Under Economic Liberalism, 1885-1950: A Reassessment Using New GDP Estimates," Review of Income and Wealth 48: 561-579 (December 2002). GDP per capita is calculated using Yousef's GDP series and population data from Mitchell (1998, p. 47).

Greece: GDP figures for 1927 and 1928 come from Michael Bordo. GDP per capita is calculated using Maddison's population series.

Hungary: GDP data for 1942 and 1943 come from Mitchell (1992, p. 894). Population data is from Maddison.

India: Population and GDP per capita data for 1873-1899 are taken from Moni Mukherjee, National Income of India, Trends and Structure (Calcutta: Statistical Publishing Society, 1969). The implicit GDP series is computed from these data, converted into real 1990 dollars in the standard manner, and then divided by population to generate real GDP per capita.

Mexico: Figures for 1895-1899 come from Mitchell (1993, p. 749).

Paraguay: GDP and population data for 1938-1954 come from Mitchell (1993, pp. 767, 63-64, respectively).

Phillippines: GDP figures for 1946-1949 are taken from Mitchell (1998, p. 1012); population data are from Maddison.

Portugal: Figures for 1880-1914 come from Bordo and Rockoff (1996).

Soviet Union: The average of GDP for 1940 and 1945 from Maddison is used to fill in observations for 1941-1944; the average of per capita GDP for 1940 and 1946 from Maddison is used to fill in 1941-1945.

Spain: Figures for 1870-1954 come from Leandro Prados de la Escosura, El progreso económico de España: 1850-2000 (Madrid: Fundación BBVA, 2002).

Uruguay: Figures for 1870-1954 are taken from Luis Bértola et al., El PBI de Uruguay 18701936 y otras estimaciones (Montevideo: 1999). GDP and GDP per capita data are given in index level form, with $1913=100$. To convert into real 1990 dollars, the index series is multiplied by Maddison's GDP value in 1913. Likewise, the implicit population index series from Bértola et al is computed and converted into actual population terms using Maddison's 1913 population value. These population figures are then used to calculate GDP per capita.

Maddison (1995) reports GDP and GDP per capita series based on 1990 borders. We adjust these data to take account of the effects of historical changes in borders on economic activity, under the assumption (typically employed by Maddison) that such effects are proportionate to differences in population. Maddison's Appendix H provides population figures for selected countries in 1913 and 1939 for the borders existing at the time as well as for their 1990 borders. We adjust his GDP series based on 1990 borders by using the ratio of population within the 1913 and 1939 borders to the population within 1990 borders. (These adjustments are made only if the population difference was more than 3 percent.) Adjustments based on the 1913 ratios were applied over the 1870-1917 period for Austria-Hungary, Bulgaria, Denmark, France, Germany, Greece, Italy, Romania, Russia, Serbia/Yugoslavia, and the United Kingdom. Adjustments based on the 1939 ratios were applied to the 1918-1944 period for Bulgaria, Czechoslovakia, Germany, Italy, Poland, Romania, Russia/Soviet Union, and Serbia/Yugoslavia. Adjustments were also made for border changes affecting Korea in 1945, India in 1948, and Pakistan in 1972.

GDP per capita figures generally are assumed unaffected by these border adjustments, with the exception of Germany and Italy, for whom Maddison reports separate per capita figures for 1913, 1939, and 1990 borders. 


\section{Land Area}

Land area figures were taken from the World Factbook (Washington, D.C.: Central Intelligence Agency, 2000). For the period 1870-1917 land area data for Albania, Austria-Hungary, Belgium, Denmark, Finland, France, Germany, Greece, Korea, the Netherlands, Norway, Romania, Russia/USSR, Sweden, and Turkey were obtained from the online replica of the Encyclopedia Britannica, $11^{\text {th }}$ edition (Cambridge: University Press, 1911). Figures for the 1918-1944 period for Albania, Austria, Belgium, Czechoslovakia, Denmark, Estonia, Finland, France, Greece, Hungary, Korea, Latvia, Lithuania, the Netherlands, Norway, Poland, Romania, Sweden, Turkey, USSR (Russia), Germany, and Yugoslavia are taken from the New World Looseleaf Atlas (New York: Hammond, $6^{\text {th }}$ edition, no date, circa 1920s). 